\title{
Up, down, and across the land: landscape terms, place names, and spatial language in Tzeltal
}

\author{
Penelope Brown *
}

Max Planck Institute for Psycholinguistics, Language Acquisition, PB 310, NL 6500 AH Nijmegen, Netherlands

\begin{abstract}
The Tzeltal language is spoken in a mountainous region of southern Mexico by some 280,000 Mayan corn farmers. This paper focuses on landscape and place vocabulary in the Tzeltal municipio of Tenejapa, where speakers use an absolute system of spatial reckoning based on the overall uphill (southward)/downhill (northward) slope of the land. The paper examines the formal and functional properties of the Tenejapa Tzeltal vocabulary labelling features of the local landscape and relates it to spatial vocabulary for describing locative relations, including the uphill/downhill axis for spatial reckoning as well as body part terms for specifying parts of locative grounds. I then examine the local place names, discuss their semantic and morphosyntactic properties, and relate them to the landscape vocabulary, to spatial vocabulary, and also to cultural narratives about events associated with particular places. I conclude with some observations on the determinants of landscape and place terminology in Tzeltal, and what this vocabulary and how it is used reveal about the conceptualization of landscape and places.

(C) 2006 Elsevier Ltd. All rights reserved.
\end{abstract}

Keywords: Landscape; Tzeltal; Place names; Space; Absolute frame of reference

\section{Introduction}

This paper addresses the conceptualization of a people's environment - natural and manmade features of the landscape - by looking at how these are coded in their language and expressed in language usage. The issue here is one of geographical ontology and its

\footnotetext{
${ }^{*}$ Fax: +31243521300 .

E-mail address: Penelope.Brown@mpi.nl
} 
relation to spatial language and cognition - do these vary cross-linguistically, cross-culturally, even across ecologically similar environments? What kinds of categories do people pick out with landscape and place terminology? Is reference to places distinguished from reference to things (people, animal, objects) AT places? Are place names formally distinguished from other kinds of proper names and from common nouns - and if so, how? What places do they refer to? How are they semantically construed?

Two streams of interest converge in these questions. On the one hand, there is the issue of the ontological status of landscape terms across different languages - do they provide evidence for universal properties of human cognition (Smith and Mark, 1999, 2003)? On the other hand, among anthropologists and linguists concerned with spatial language and conceptualization across languages and cultures, landscape terms and place names offer a critical arena for understanding how members of a community conceptualize their spatial environment (e.g. Basso, 1984; Hirsch and O’Hanlon, 1995; Hunn, 1996; Hercus et al., 2002).

I address these questions with data from a Mayan community in southern Mexico. ${ }^{1}$ The people in question are Tzeltal Mayans living in a precipitously mountainous region of the state of Chiapas; they are slash and burn agriculturalists leading a largely subsistence existence based on corn and beans cultivation, supplemented where ecology permits with a cash crop of coffee. There are 280,000 or more Tzeltal speakers spread across the state of Chiapas, from the high mountain plateau of San Cristóbal de las Casas and environs to the lowland jungle of southeastern Chiapas. I confine myself here to the rural highland community of Tenejapa, ${ }^{2}$ focussing especially on the paraje (hamlet) of Majosik', where I have worked for over 30 years.

The paper examines the formal and functional properties of the Tenejapa Tzeltal vocabulary used for labelling features of the local landscape and relates it to spatial vocabulary used for describing locative relations, including the uphill/downhill axis for spatial reckoning as well as body part terms for specifying parts of locative grounds. I then examine the local toponyms - place names that pick out individual landscape or other place features enabling their unique identification - particular rivers, mountains, valleys, settlements of different types, neighboring municipios, as well as more local features like trails, cliffs, lakes, ritually important places, and ad hoc meeting-places. Many of these place names incorporate landscape features as part of the name (e.g. 'Red Cliffs', 'Lake'), while others refer to salient physical characteristics of the locality (e.g. 'Place_of_many small_(gravel)_stones'). I describe the semantic and morphosyntactic properties of these names, and again connect them to spatial vocabulary but also more generally to cultural narratives about events associated with particular places.

The argument I propose is this: Tzeltal landscape and place terminology and the use of these terms in locative expressions reflect a cognitive template, a conceptualization of the local environment as a 'tilted world', an inclined plane sloping down to the north. This template underlies locative expression in Tzeltal from the large scale ('Veracruz is downhill from Tenejapa') to the small scale ('the machete is standing leaning downhill from the

\footnotetext{
1 The data is based on my own fieldwork in this community since 1971. Intensive elicitation about landscape terms and place names was conducted by me with several Tenejapan consultants in field trips in 2001-2006, based on methods set out in the MPI Field Manuals (Bohnemeyer, 2001; Bohnemeyer et al., 2004).

2 The center of Tenejapa municipio is approximately at latitude $16^{\circ} 50^{\prime}$ North and longitude $92^{\circ} 50^{\prime}$ West (Hunn, 1977, p. 5).
} 
doorway'). It also permeates the use of place names and landscape terms in speech about the environment, for example in route descriptions and narratives.

First we will need some background on the ecological context, and on two aspects of the linguistic context: the absolute spatial reckoning system, and spatial relators in Tzeltal vocabulary.

\section{The ecological context}

Tenejapa is a municipio - a corporate community with its own identity, clothing, and local government - of about 100 square kilometers, situated in a rugged, mountainous area of highland Chiapas. It lies at the western edge of Tzeltal-speaking territory, bordered by municipios of Tzotzil speakers from the northwest to the southeast (see Fig. 1). Elevations range between $900 \mathrm{~m}$ (2925 feet) in the northeast to $2800 \mathrm{~m}$ (9100 feet) in the south. Rainfall amounts to perhaps $1500 \mathrm{~mm}$ a year, which falls mostly in the rainy season between May and December (Hunn, 1977, p. 5).

Because of the dramatic variation in altitude, the municipio is split conceptually in half, into high sikil k'inal, 'cold country', characterized by pine and oak covered ridges, and low k'ixin k'inal, 'hot country', with more tropical vegetation, an opposition reflected in many aspects of religious ritual as well as in what crops can be grown. Drainage is to the northeast, with streams flowing often underground through limestone caves, into the Tanate' River on the northern border of Tenejapa, which in turn dives underground for many miles and re-emerges as the Chacte' River, flowing eventually into the Grijalva and thence into the Pacific Ocean (Hunn, 1977, p. 5; see Fig. 2).

The fragmented land tenure system of Tenejapa allows most families to exploit the different ecologies, with distinct crops in lowland fields and upland fields, reached by following the ridge or valley which runs down from the south to the north. Most travel was until very recently by foot, over an extensive set of trails, most of which run south/north following the prevailing ridges and valleys. Tenejapans travelled on foot quite widely outside the municipio to markets and to the town of San Cristóbal, acquiring an intimate knowledge of the local landscape. Roadbuilding, however, has been intensive in the last decade, so even the most remote communities now have a rough dirt road into them and travel by foot is correspondingly diminished.

The population of Tenejapa is about 37,000, and the land is densely used. Settlement is in dispersed hamlets (known as parajes), with household compounds spread out and surrounded with cultivated fields, fallow land, banana and other fruit trees, and, in hot country, coffee plantations.

The focus in this paper is on the paraje of Majosik', a settlement located at the northern extreme of Tenejapa (see Fig. 2), and hence in 'hot country' from a Tenejapa-wide perspective. The paraje sits in a large high crescent-shaped basin in the south, sloping down into a wide valley and up to the western slopes of a long ridge running about four miles downhillwards from a high point in the south to the river Tanate' in the north, which bounds the Tzeltal-speaking world (over the border in Chenalho' they speak a related Mayan language, Tzotzil). ${ }^{3}$ The shift in altitude from the southern end of Majosik' (c. 5300 feet, or

\footnotetext{
${ }^{3}$ Tanate' is one of the smaller tributaries of the Rio Grijalva (Berlin et al., 1974).
} 


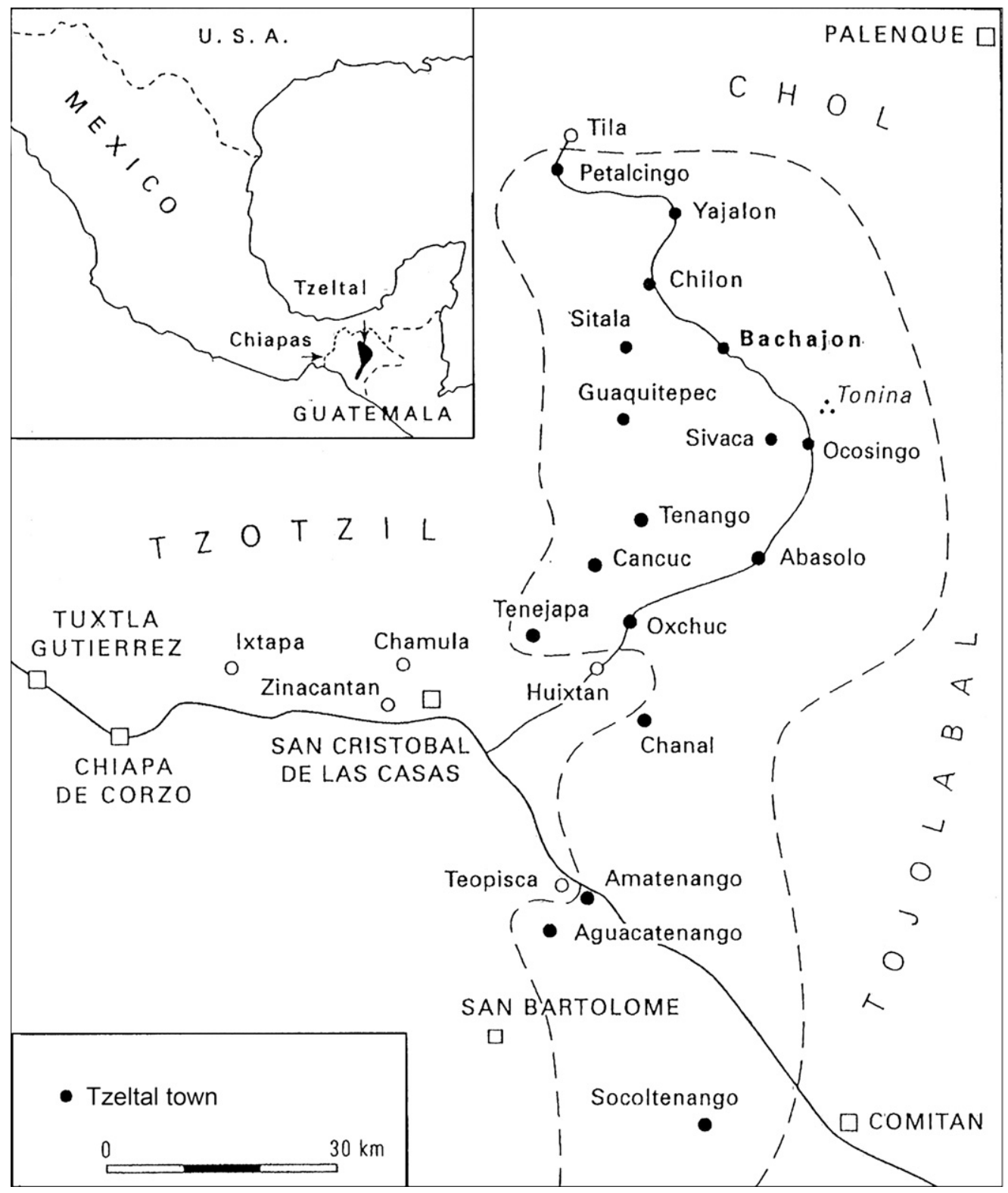

Fig. 1. Map of Tzeltal/Tzotzil area (adapted from Monad Becquelin, 1997 based on Breton, 1979, p. 16).

$1600 \mathrm{~m}$ ) to the northern end (c. 3000 feet, or $900 \mathrm{~m}$ ) has dramatic ecological effects - from pine forest to semi-tropical conditions (see Figs. 3-5).

Most ridges in the surrounding area run parallel. The high, cold, ceremonial centre of Tenejapa (locally referred to as Lum 'town', c. 6700 feet, $2000 \mathrm{~m}$ ) lies clearly uphill and due south of Majosik'. Lum is a small town with some Spanish-speaking Mexican inhabitants (Ladinos, in local parlance) as well as Tzeltal ones, primarily political and religious leaders housed in town during their tenure (see Fig. 6). Beyond that, $30 \mathrm{~km}$ to 


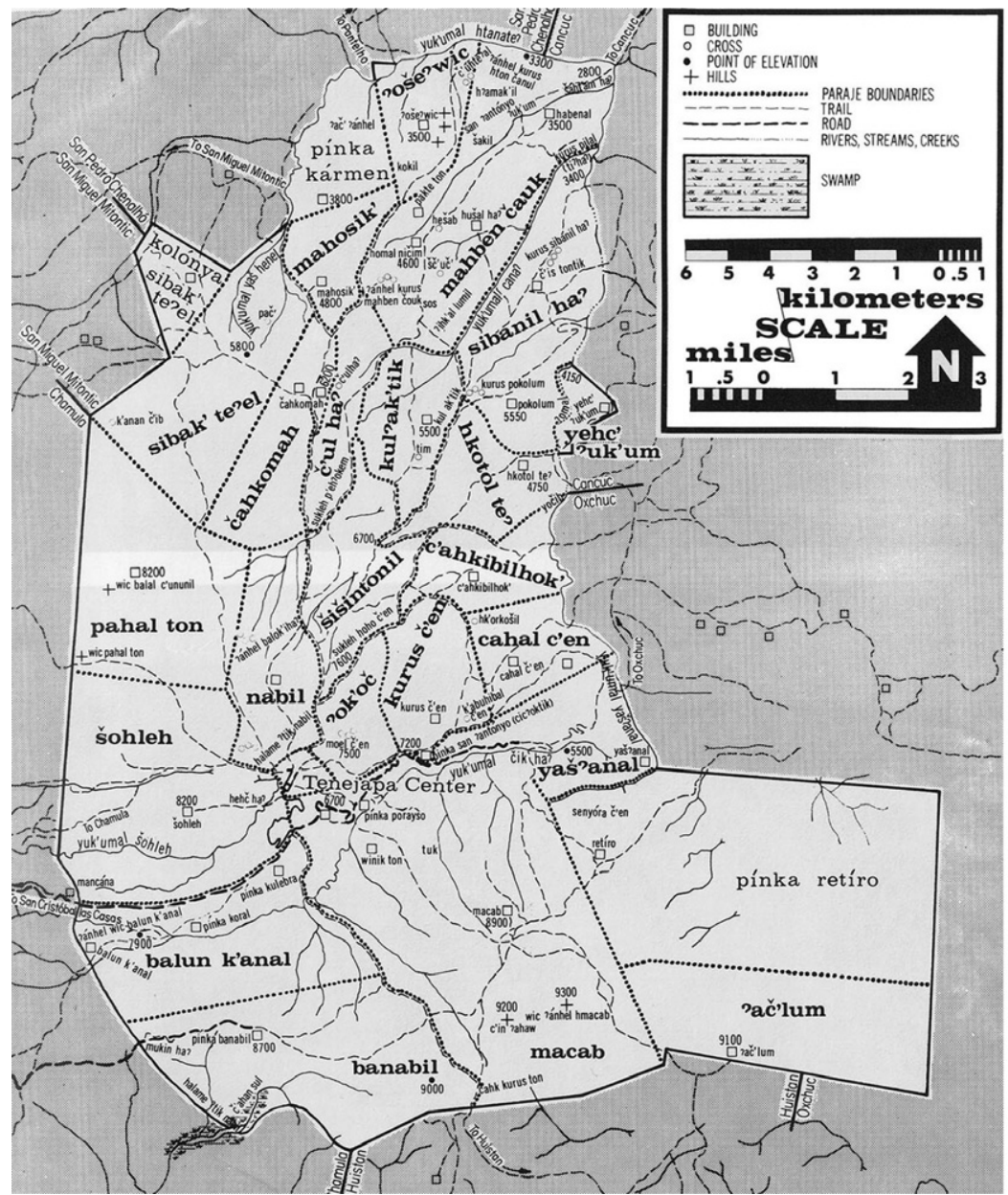

alan 'downhill'

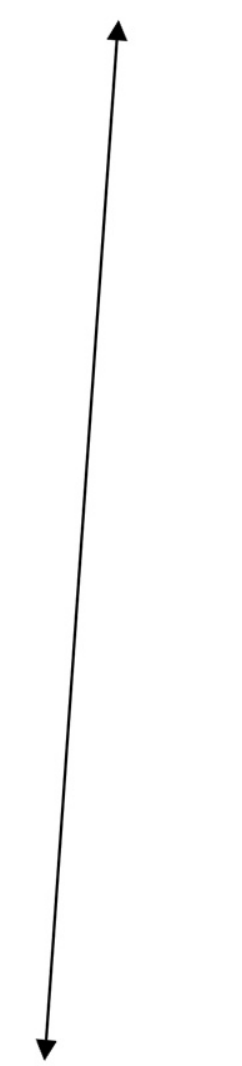

ajk'ol 'uphill'

Fig. 2. Map of Tenejapa (from Berlin et al., 1974, p. 17).

the southwest and still in cold high country, lies the market town of San Cristóbal, the furthest limit of travel for most inhabitants of the remoter parajes because of the scarcity of roads and the precipitateness of the country.

\section{Spatial language in Tzeltal}

\subsection{The 'uphill/downhill' system}

Tzeltal spatial language is notable for the absence of any relative left/right/front/back system for describing spatial relations. Instead there is an absolute 'uphill/downhill' system based ultimately on the overall general slope of the land in this region (downward from high south to low north) (Brown and Levinson, 1993; Levinson, 2003; Brown, 2006). This has however been abstracted to yield an abstract cardinal direction axis, analogous to south/north although systematically skewed from the cartographic axis of standard maps. Together with an orthogonal axis, labelled 'across' at both ends, this provides 


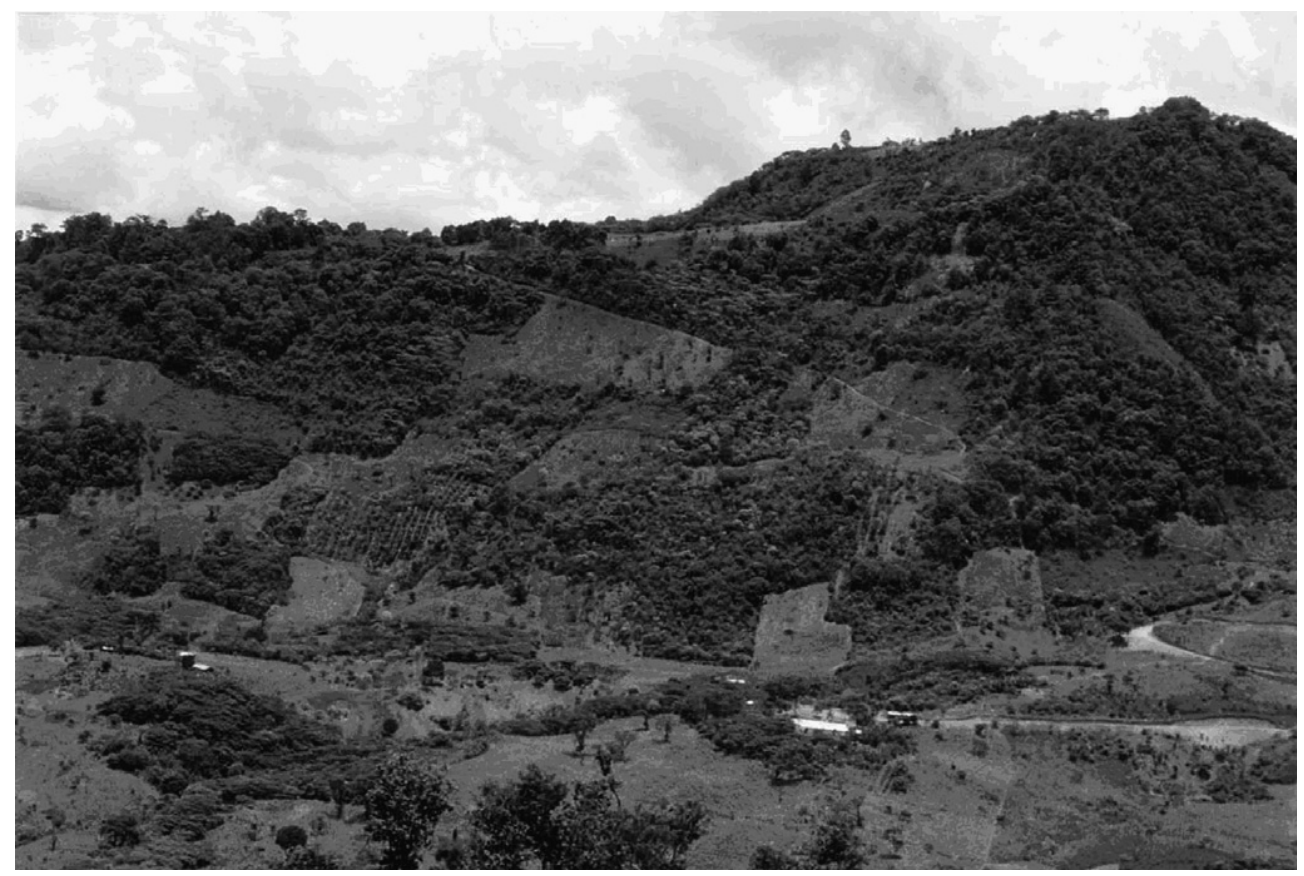

Fig. 3. Photograph of ajk'ol in Majosik', facing southeast where the road from Lum comes in.

a system of cardinal directions. The absolute terms are used routinely to describe the locations of things, either with respect to each other or with respect to protagonists or speakers, on both a large scale (locations in the landscape) and on a small scale (locations within, say, arm's reach). So of two bottles on either end of a north-south oriented table, one will be described quite naturally as 'to downhill' of the other, even though the table is horizontal. Here the overall lie of the territory provides a fixed angle (of orientation, in the horizontal plane) which can be used to describe the directional relation of things that are not actually inclined with respect to one another (see Fig. 7).

Because there is no relative system (with notions like 'to the left of', etc.), ${ }^{4}$ this absolute system plays a crucial role in linguistic descriptions of location. Thus in Tzeltal one describes static spatial relationships as in the following examples ${ }^{5}$ :

\footnotetext{
${ }^{4}$ There are terms for the 'left' (xin) and 'right' (wa' el) hands, but these terms are not used in a relative frame of reference to project egocentric axes for establishing spatial relations (Brown and Levinson, 1993).

${ }^{5}$ Tzeltal transcription conventions are based on a practical orthography. Symbols correspond roughly to their English equivalents except that $j=h, x=s h$, and 'indicates a glottal stop or glottalization of the preceding consonant. This orthography postdates 1977, which is why place names in Figs. 2 and 10 are spelled slightly differently from those in my text, with $c$ instead of $t z$, č instead of $c h$, š instead of $x$, and $h$ instead of $j$. Abbreviations for glosses are as follows: 1,2,3 E indicates 1st, 2nd, 3rd person ergative prefixes (marking both subjects of transitive verbs and noun possession), 1,2,3 A indicates the corresponding absolutive suffixes, $1 \mathrm{plex}$ is 1st person plural exclusive, 1 plin lst person plural inclusive, PL 2nd or 3rd person plural, DIST distributive/plural, ASP neutral aspect, CMP completive aspect prefix, ICP incompletive aspect prefix, ADJ predicate adjective -VI suffix, ART article, AUX auxiliary verb, CL clitic, DIR directional, DIS dispositional stative derivation, EXIST existential predicate, NC numeral classifier, PERF perfective, PREP preposition, PT particle, QUO quotative particle, REDUP reduplication, RELN relational noun.
} 


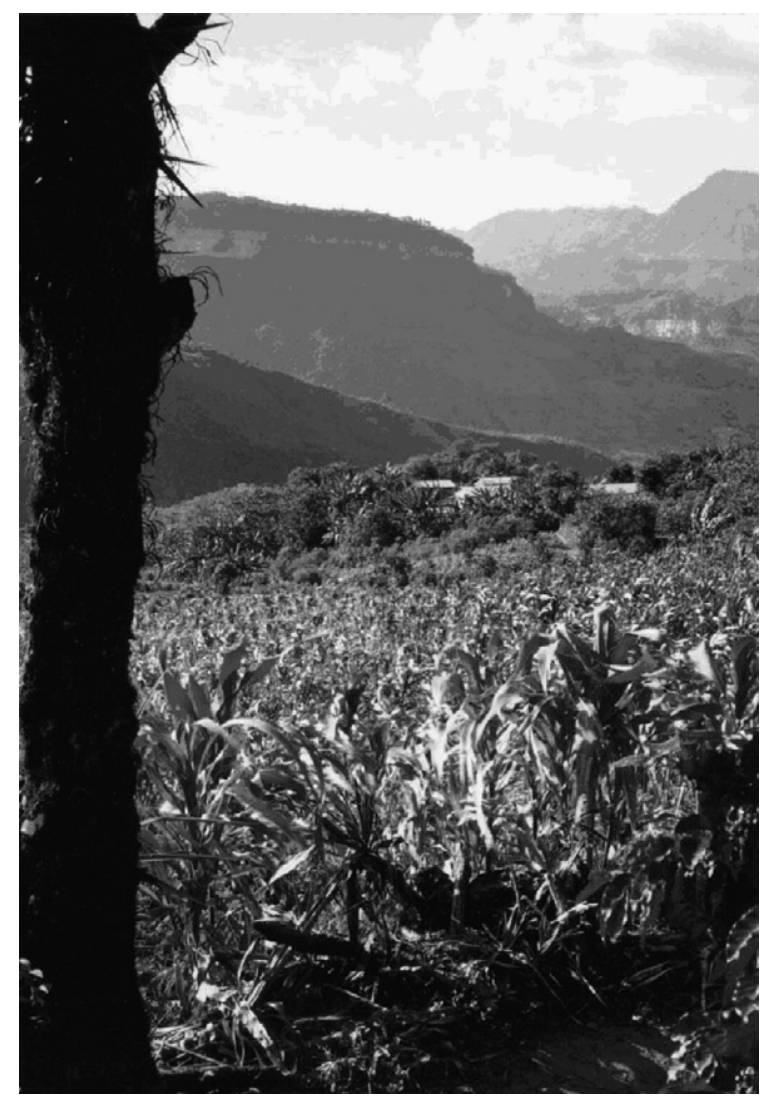

Fig. 4. Photograph from Oxeb Witz, facing north to alan.

$\langle 1\rangle$ a. chot-ol-0 ta y-anil amak' te tz'amalte'-e. stand-DIS-3A PREP 3E-below patio ART bench-CL

'The bench is standing 'beneath' (downhillwards/north of) the patio.'

b. tzak-be-n tal machit tey xik-il-0 ta y-ajk'ol tinel. grasp-DIT-1A DIRcome machete there lean-DIS-3A PREP 3E-uphill door 'Bring me the machete standing leaning there 'above' (uphillwards of) the door.'

Equally, spatial relations in motion are described with reference to this system, as in:

$\langle 2\rangle$ a. ya $x$-mo-0 ta Jobel te winik-e.

ICP ASP-ascend-3A PREP San Cristóbal ART man-CL

'The man is 'ascending' [i.e. going southwards] to San Cristóbal.'

b. jelaw-0 ta Colonia.

cross-3A PREP Colonia

'He 'crossed' to Colonia.' (i.e. went across (orthogonal to) the south/north slope of the land).

There is a dedicated spatial vocabulary for this purpose, consisting of (i) intransitive verb roots ('ascend', 'descend', 'go across'), (ii) their transitivized counterparts ('cause it 


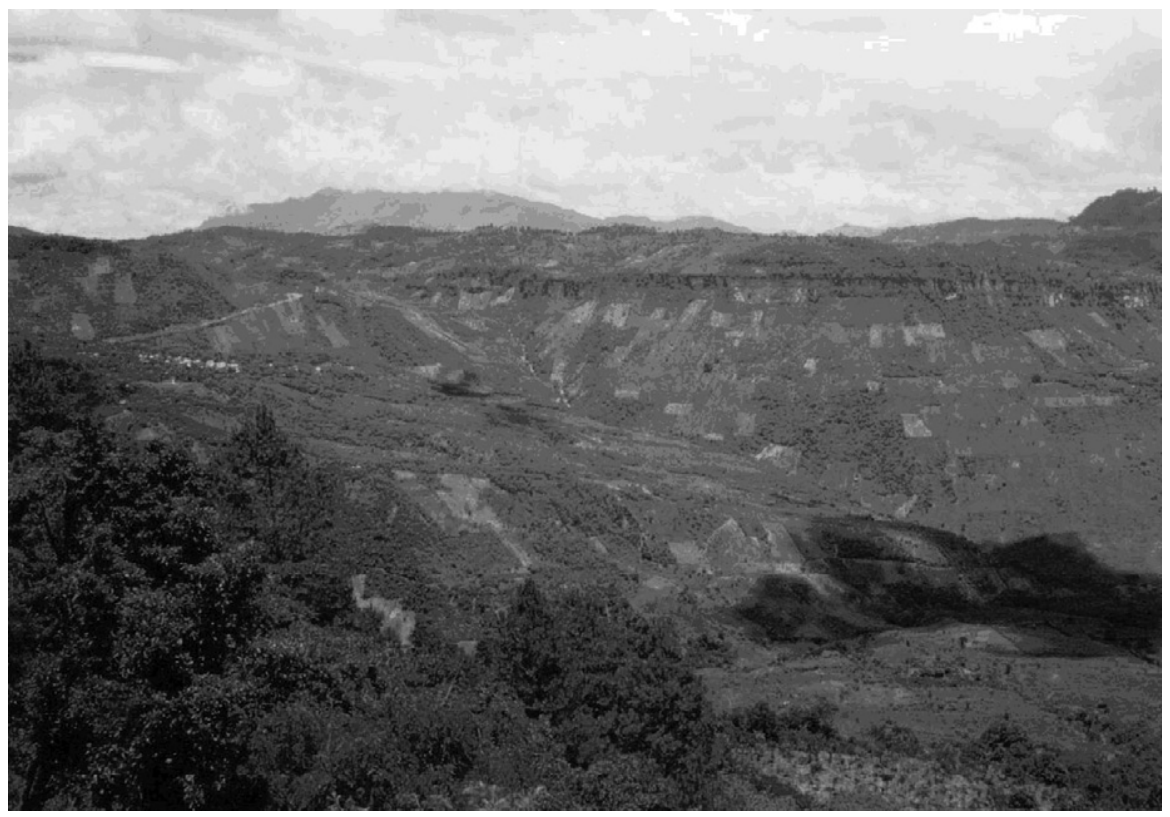

Fig. 5. Photograph from Majosik', facing northwest to jejch toward Chenalho' territory and beyond.

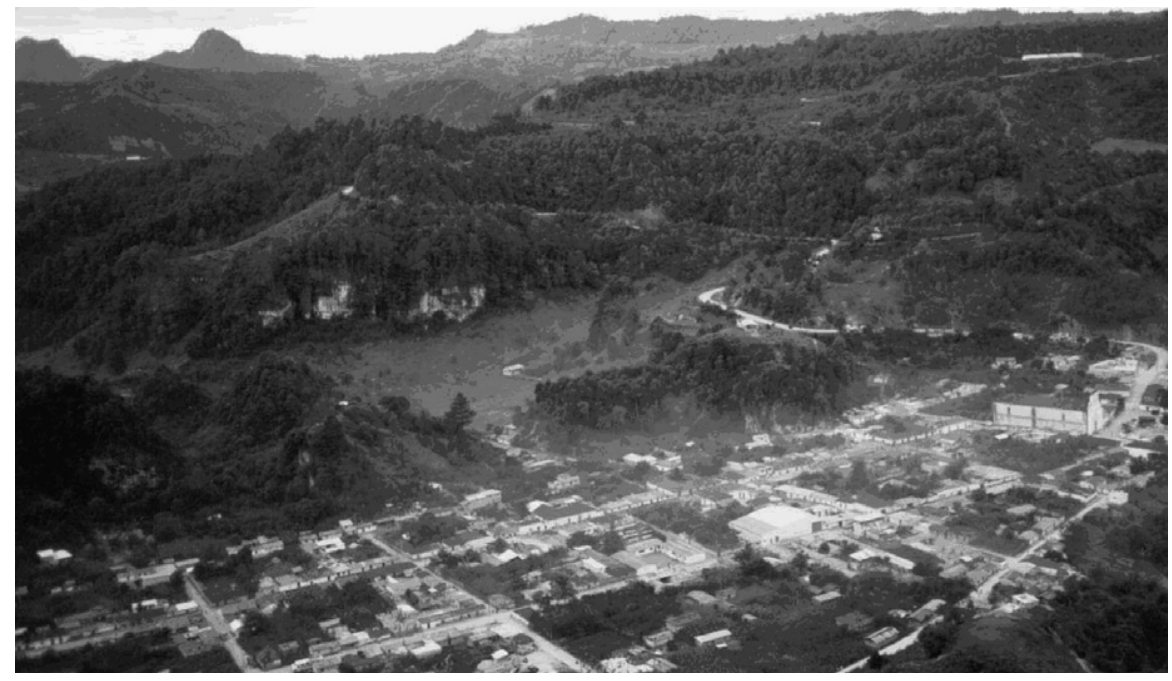

Fig. 6. Photograph of Lum, facing southwest; the two peaks of Matzab visible top left are the highest points in Tenejapa.

to ascend/descend/go across'), (iii) directional adverbs ('ascending', 'descending', 'crossing') and (iv) nouns, which may be unpossessed and hence only implicitly relational ('uphill', 'downhill', 'side') or explicitly relational possessed nouns ('its above-or-uphillside', 'its underneath-or-downhill-side'). These uphill/downhill nouns belong to the same form class as the body part terms discussed below in 3.2. 

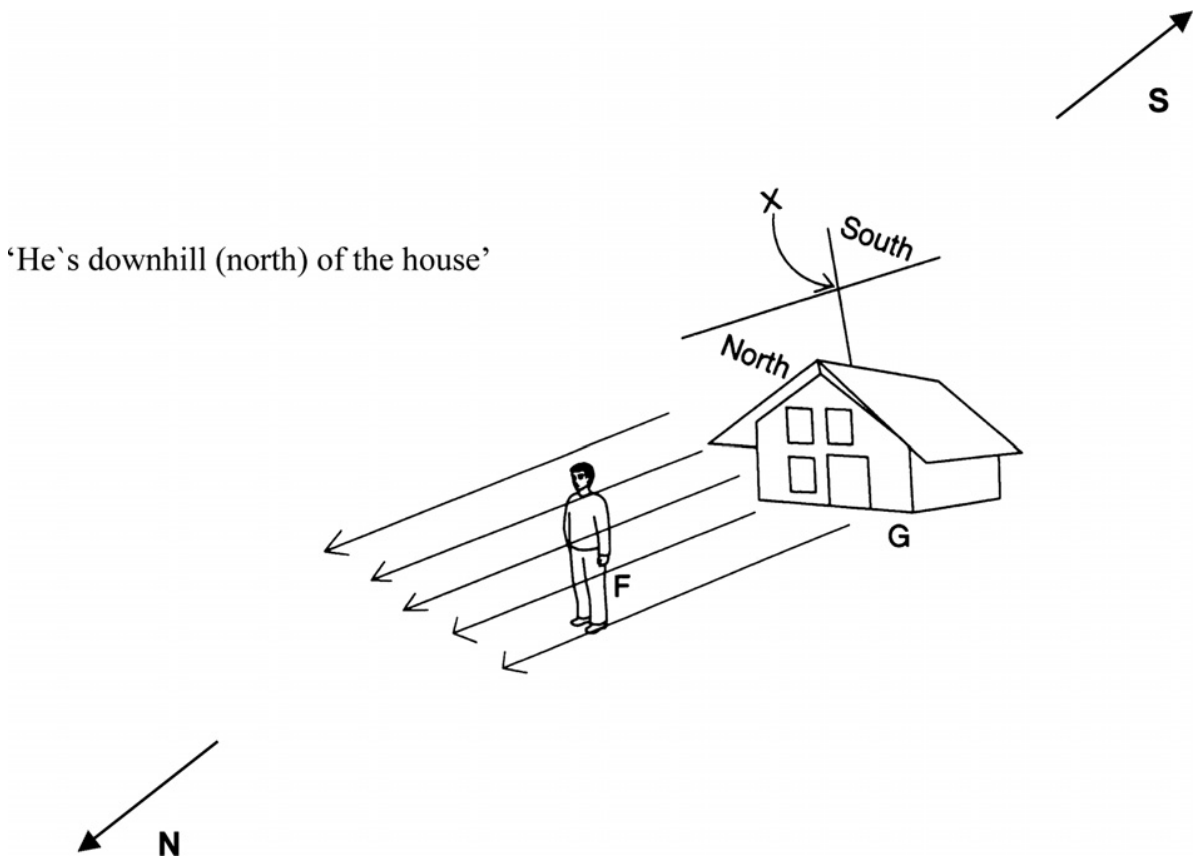

Fig. 7. The geometry of absolute coordinates (from Brown and Levinson, 2000).

One of the central uses of the notions of 'uphill/downhill' has reference to the overall inclination of the whole territory from highland south to lowland north, so in Majosik' one refers naturally to Lum (Tenejapa centre, which lies to the South of most of the parajes) as ta ajk'ol, 'to uphill', and the northern river (Tanate') marking the end of Tzeltalspeaking territory as ta alan, 'to downhill'. Though there may be local deviations from the overall inclination (e.g. an intervening hill or ridge), the terms can still be utilized to pick out positions on that overall inclined plane running down to the North. This is the use applicable to landscape and place name terms (e.g. 'Look, down there [i.e. northwards] is Blackman cave').

East and west directions can be designated as slok'ib k'aal, lit. 'the coming out of the sun' and smalib k'aal, 'the spilling of the sun', but these terms are more like landmark terms (i.e. the landmarks are the specific mountains behind which the sun rises in the east, and sets in the west) and they are not understood to label an abstract axis orthogonal to the 'uphill/downhill' axis (Brown and Levinson, 1993).

The use of 'uphill/downhill' expressions to locate entities on an idealized south/north inclined plane constitutes an 'absolute' mode of spatial description, since these terms label angles, fixed without reference to the orientation of ego or of another human body or object, with which one can describe relative positions. To use such a system one needs to be absolutely oriented (to know where the 'uphill' and 'downhill' directions are), and, indeed, Tenejapan Tzeltal speakers display a keen sense of absolute orientation and direction in their speech and gestures.

We have described this system in detail in a number of publications (Brown and Levinson, 1993; Levinson and Brown, 1994; Levinson, 2003; Brown, 2006), considering it as 
part of a Tzeltal-specific tendency to describe spatial relations without depending on an egocentric reference point. In this paper I consider it in relation to landscape terms and place names.

\subsection{Spatial relators}

A second aspect of spatial language in Tzeltal is the use of part terms as spatial relators. There is only one, generic, preposition in Tzeltal, so locative descriptions cannot rely on prepositions to distinguish spatial relations such as to, from, in, on, at, near, between, above, and below. Instead, like in many other Mesoamerican languages, locative expressions in Tzeltal make use of possessed body part terms (e.g. 'its head', 'its nose', 'its lips', 'its face', 'its belly', 'its butt', 'its foot'), ${ }^{6}$ which are mapped onto parts of inanimate objects by a precise geometrical algorithm - largely on the basis of shape (Levinson, 1994). For example:

\section{$\langle 3\rangle$ waxal-0 ta jol mexa te limete. \\ standing-3A PREP head table ART bottle}

'The bottle is at the 'head' of the table.' [head assigned to table on basis of long axis; both ends are 'head']

In addition to body part terms, other relational nouns with more abstract semantics can perform the same function - allowing precise specification of where the object is in relation to the overall 'uphill/downhill' lay of the land - as in:
〈4) ya x-a'tej-on
ICP ASP-work-1ABS
ta y-e'tal k'altik.
PREP 3E-bottom cornfield

'I'm working at the 'bottom' of the corn field.' ['bottom', here applies to the downhillmost (north) edge of the cornfield]

Table 1 gives the body part and relational noun terms used in locative expressions in Tzeltal. As we shall see, some but not all of these terms apply to physical features of the landscape and appear in place names based in landforms.

In general, there is a division of labour between the subset of spatial nouns that are used in the absolute system (ajk'ol, alan, -anil), which tend to be used for describing spatial relations across any distance greater than a foot or two, and the body part terms which are applicable to spatial relations of contiguity (see Brown and Levinson, 1993).

\section{Land form terms}

\subsection{Formal and functional properties}

The Tzeltal landscape vocabulary, widely construed to include both natural and manmade features, is listed in Tables 2-4. These labels reflect the local ecology and preoccupations.

\footnotetext{
${ }^{6}$ Possession marking (with the ergative prefix) is variable, sometimes omitted especially with geographic labels. In example $\langle 3\rangle$ it is omitted on the noun jol, but in example $\langle 4\rangle$ it is present on the noun $y$-e'tal 'bottom'; in fact it is obligatory on most spatial nouns beginning with a vowel.
} 
Table 1

Spatial nouns in Tzeltal locatives (from Brown, 2006)

\begin{tabular}{|c|c|c|c|}
\hline \multicolumn{4}{|c|}{ Body part terms } \\
\hline \multicolumn{2}{|l|}{ Root } & \multicolumn{2}{|c|}{ Possessed form } \\
\hline jol & 'head' & ta s-jol & 'at its head' \\
\hline & 'back' & ta s-pat & 'at its back' \\
\hline ch'ujt & 'stomach' & ta $x$-ch'ujt & 'at its belly' \\
\hline -akan & 'foot' & ta $y$-akan & 'at its foot' \\
\hline$k^{\prime} a b$ & 'arm, hand, branch' & ta $s-k^{\prime} a b$ & 'at its hand/branch' \\
\hline$-i t$ & 'butt, rump' & ta $y$-it & 'at its rump' \\
\hline$n i$ & 'nose' & ta $s-n i$ & 'at its nose' \\
\hline -elaw & 'face' & ta $y$-elaw & 'at its face' \\
\hline sit & 'eyes, face' & ta s-sit & 'at its eyes/face' \\
\hline$t i^{\prime}$ & 'mouth, lips' & ta s-ti'(il) & 'at its mouth/edge' \\
\hline chikin & 'ear' & ta $x$-chikin & 'at its ear/corner' \\
\hline$n u k^{\prime}$ & 'neck' & ta s-nuk' & 'at its neck' \\
\hline xujk & 'side, corner' & ta $(s)-x u j k$ & 'at its side' \\
\hline$-o k$ & 'lower extremities, base, trunk' & ta $y$-ok & 'at its base' \\
\hline ne & 'tail' & ta s-ne & 'at its tail' \\
\hline \multicolumn{4}{|c|}{ Relational nouns } \\
\hline \multicolumn{4}{|c|}{ ta $y$-util 'at its inside; inside it' } \\
\hline \multirow{3}{*}{\multicolumn{4}{|c|}{$\begin{array}{ll}\text { ta } y \text {-anil 'underneath it; in its enclosed underneath area; 'downhillwards' of it' } \\
\text { ta } s \text {-ba } \\
\text { ta } y \text {-e'tal 'at its top side or edge (vertically, e.g. of a table; or 'uphillwards', e.g. of a cornfield)' } \\
\text { 'at its bottom edge (vertically, e.g. bottom of a stack of tortillas, or downhillwards edge, e.g. of a field } \\
\text { or patio)' }\end{array}$}} \\
\hline & & & \\
\hline & & & \\
\hline \multicolumn{4}{|c|}{ ta y-ajk'ol 'at its uphill side; above it' } \\
\hline \multicolumn{4}{|c|}{ at its downhill side, below it' [more co } \\
\hline \multicolumn{4}{|c|}{ 'straight ahead of it' } \\
\hline \multicolumn{4}{|c|}{ 'at its half $(=$ middle $)$ '; 'be } \\
\hline \multicolumn{4}{|c|}{ 'at its side' (of a road, school, doorw } \\
\hline
\end{tabular}

Formally, Tzeltal landscape terms (widely construed) are almost all nouns, and display the variability in form that nouns in Tzeltal have. Many are monomorphemic (e.g. witz 'mountain/hill', ch'en 'cliff/cave', uk'um 'river/stream'). Some are compound (e.g. be-ja' 'rivulet, very small stream' [lit. 'path-water'], belal-karo 'road' [lit: 'path-car'). Some incorporate attributives (e.g. jochol k'inal 'empty land', unin k'inal 'young land', yijil k'inal 'mature land', specifying types of land varying by use). A very few incorporate verbs (e.g. xchakoj uk'um 'river has split it' for a deep ditch carved by a stream).

The nominal landscape terms listed in Tables 2-4 - including natural landscape features, manmade features, and features of the soil and plant cover - seem to form a lexical category of their own, on the basis of one morphological peculiarity: they take a distinctive set of plural endings. The plural for most common nouns ${ }^{7}$ is -etik (e.g. ach'ix-etik 'girls', wamal-etik 'weeds'), an ending also applicable to some landscape terms (e.g. ch'en-etik 'caves', $u k$ 'um-etik 'rivers') and to some man-made features of the environment (e.g. eskwela-etik 'schools', karetera-etik 'roads'). This ending also forms words designating the people from a named place (e.g. K'ankujk-etik 'people of K'ankujk). But landscape features

\footnotetext{
${ }^{7}$ Plural is optionally marked, and rarely on inanimate nouns.
} 
Table 2

Terms for natural features of the physical landscape

\begin{tabular}{|c|c|c|c|c|c|}
\hline & Tzeltal word & -etik plural ${ }^{\mathrm{a}}$ & $\begin{array}{l}\text {-Vltik plural } \\
\text { ("region with } \\
\text { many ...") }\end{array}$ & $\begin{array}{l}\text { Distributive } \\
\text { plural -tikil } \\
\text { ("place of. ..") }\end{array}$ & $\begin{array}{l}\text { Reduplicated } \\
\text { plural ('multiple } \\
\text { instances of...') }\end{array}$ \\
\hline $\begin{array}{l}\text { mountain, hill } \\
\text { small hill }\end{array}$ & $\begin{array}{l}\text { witz } \\
\text { t'olt'ol witz }\end{array}$ & witzetik & - & witztikil & - \\
\hline volcano & $\begin{array}{l}\text { switzul tan lit: 'its- } \\
\text { ashes mountain' }\end{array}$ & switzul tanetik & - & - & - \\
\hline $\begin{array}{l}\text { ridge of a } \\
\text { mountain }\end{array}$ & $\begin{array}{l}\text { stenlejal jol witz 'its- } \\
\text { flat-place head of } \\
\text { mountain' }\end{array}$ & $\begin{array}{l}\text { stenlejal } \\
\text { jolwitzetik }\end{array}$ & - & - & $\begin{array}{l}\text { stenlejal } \\
\text { joljolwitz }\end{array}$ \\
\hline ridges & tzelel witz & tzelel witzetik & - & - & - \\
\hline $\begin{array}{l}\text { pass, low place in } \\
\text { ridge of } \\
\text { mountains } \\
\text { incl. its rising } \\
\text { sides }\end{array}$ & ya'tal & $\begin{array}{l}\text { yat'ajtik } \\
\text { witzetik }\end{array}$ & - & - & - \\
\hline cave/cliff & ch'en & ch'enetik & - & ch'entikil & - \\
\hline $\begin{array}{l}\text { limestone } \\
\text { sinkhole }\end{array}$ & $x a b$ & xabetik & xabileltik & - & - \\
\hline river/stream & $u k^{\prime} u m$ & uk'umetik & uk'umaltik & - & - \\
\hline $\begin{array}{l}\text { small stream, } \\
\text { rivulet }\end{array}$ & $\begin{array}{l}\text { beja' [lit: 'trail- } \\
\text { water'] }\end{array}$ & beja'etik & beja'iltik & - & - \\
\hline $\begin{array}{l}\text { place where water } \\
\text { enters ground }\end{array}$ & yochib ja' & $\begin{array}{l}\text { yochib ja'etik } \\
\text { [lit: 'its- } \\
\text { entering- place } \\
\text { water'] }\end{array}$ & - & - & - \\
\hline waterhole, spring & $\begin{array}{l}\text { uch'oj ja'il [lit: } \\
\text { 'drink-place water'] }\end{array}$ & uch'oj ja'etik & uch'oj ja'iltik & - & - \\
\hline marsh, wetland & tz'ajel & tz'ajeletik & tz'ajelaltik & - & - \\
\hline $\begin{array}{l}\text { deep ditch made } \\
\text { by river }\end{array}$ & $\begin{array}{l}\text { xch'akoj uk'um/beja' } \\
\text { [lit. 'river has split } \\
\text { it'] OR ch'akul } \\
\text { uk'um }\end{array}$ & $\begin{array}{l}\text { xch'akul } \\
\text { uk'umetikl } \\
\text { beja'etik }\end{array}$ & $\begin{array}{l}\text { xch'akoj } \\
\text { beja'eltik (lots) }\end{array}$ & - & - \\
\hline lake with outlet & nabil & nabiletik & $\begin{array}{l}\text { nabileltik or } \\
\text { nabilaltik }\end{array}$ & - & - \\
\hline $\begin{array}{l}\text { puddle or lake } \\
\text { without outlet }\end{array}$ & $\begin{array}{l}\text { pampam ja' } \\
\text { 'spread_out- } \\
\text { spread_out water' }\end{array}$ & pampamja'etik & $\begin{array}{l}\text { pampamja'- } \\
\text { iltik }\end{array}$ & - & - \\
\hline waterfall & $\begin{array}{l}\text { ya xyal ja' ['water } \\
\text { falls'], or yalib ja } \\
\text { ['waterfall place'] }\end{array}$ & yalib ja'etik & yalib ja'eltik & - & - \\
\hline valley & omal & omaletik & omaleltik & - & - \\
\hline canyon & $\begin{array}{l}\text { xatal witz ['split } \\
\text { mountain'] }\end{array}$ & xatal witzetik & - & xatal witztikil & \\
\hline $\begin{array}{l}\text { desert, dried up } \\
\text { area }\end{array}$ & $\begin{array}{l}\text { takin balamilal / } \\
\text { k'inal/lum'dry land' }\end{array}$ & $\begin{array}{l}\text { takin } \\
\text { balamilaletik }\end{array}$ & - & - & - \\
\hline plain, flat area & stenlej & stenlejetik & stenlejal(tik) & - & - \\
\hline $\begin{array}{l}\text { open vista (land } \\
\text { drops away so } \\
\text { can see far) }\end{array}$ & elawal 'face' & elawaletik & - & - & - \\
\hline ocean & muk'ul nabil, mar & $\begin{array}{l}\text { muk'ul } \\
\text { nabiletik }\end{array}$ & $\begin{array}{l}\text { muk'ul } \\
\text { nabilaltik }\end{array}$ & - & - \\
\hline
\end{tabular}


Table 2 (continued)

\begin{tabular}{|c|c|c|c|c|c|}
\hline & Tzeltal word & -etik plural $^{\mathrm{a}}$ & $\begin{array}{l}\text {-Vltik plural } \\
\text { ("region with } \\
\text { many ...") }\end{array}$ & $\begin{array}{l}\text { Distributive } \\
\text { plural -tikil } \\
\text { ("place of...") }\end{array}$ & $\begin{array}{l}\text { Reduplicated } \\
\text { plural ('multiple } \\
\text { instances of...') }\end{array}$ \\
\hline earth & lum & $\begin{array}{l}\text { not possible } \\
\text { (there is only } \\
\text { one) }\end{array}$ & lumilal(tik) & $\begin{array}{l}\text { (lumtikil) } \\
\text { 'many towns' }\end{array}$ & - \\
\hline sky & ch'ulchan & $\begin{array}{l}\text { (there is only } \\
\text { one) }\end{array}$ & - & - & - \\
\hline world & balamilal & $\begin{array}{l}\text { (there is only } \\
\text { one) }\end{array}$ & - & - & - \\
\hline
\end{tabular}

${ }^{a}$ The plural -etik indicates many, not just two or three.

are pluralized distributively by one (or occasionally more than one) of three alternative endings, indicating a place or region characterised by many instances of the labelled landscape feature: (i) -tikil (e.g. ch'en-tikil 'place of many caves', ton-tikil 'place of many stones'), (ii) -Vltik (where the $\mathrm{V}$ is a vowel attuned to the first vowel in the word) (e.g. xabil-eltik 'place of limestone sinkholes', beja'-iltik 'place of many rivulets'), and (iii) reduplication (e.g. lum-lum-tik 'place of many towns close to each other', na-na-tik 'place of many houses').

Indeed, as Tables 2-4 show, the -Vltik distributive plural is a relatively productive way of producing terms designating features of the landscape and manmade physical environment, and it extends to nonpermanent environmental features due to human use - e.g. banana patches, cornfields, coffee plantations, fields of cows or horses, as shown in Table 4. ${ }^{8}$ The -tikil ending is more restricted, applying to some features of natural landscape, plant cover and soils (Tables 2 and 4 ) but apparently not to manmade ones (Table 3), suggesting that in this respect manmade features of the environment are distinguishable from natural ones.

Are landforms treated in their terminology as objects or as places? The distributive plural markers suggest that they are treated as objects, which need the distributive plural marker to be construed as areas or regions. Another suggestion of their object-like status is how they are counted; landforms are counted with numeral classifiers (which unitize them) in the same way as common nouns:

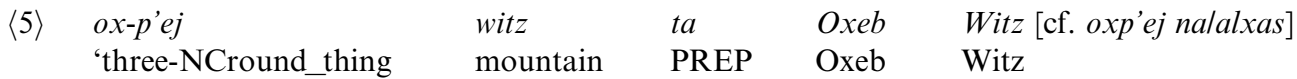

'There are three mountains in Oxeb Witz'. [cf. 'three-round_thing house/orange']

$\langle 6\rangle$ balun-kaj laj te witz-e ta Balunk'anal, s-kajal-kaj. nine-step QUO ART mountain-CL PREP Balunk'anal, 3E-on_top_of-REDUP 'There are nine steps (levels stepping up) they say, (on) the mountain in Balunk'anal, it is in steps upwards.'

\footnotetext{
${ }^{8}$ Note that Tenejapans do not raise sheep, but the neighboring Chamulas do and this is important as the source of wool for traditional Tenejapan clothes. Informants rejected the distributive plural *chijeltik 'place of sheep', claiming that instead you would say something like ila'wil balenta chij! 'Look, lots of sheep!', suggesting that these distributive plural forms are semi-frozen expressions. Alternatively, perhaps you cannot say ch'ijeltik because, unlike Tenejapan horses and cows, sheep do not occupy a delimited place, but roam unfettered.
} 
Table 3

Terms for manmade features of the landscape and physical environment

\begin{tabular}{|c|c|c|c|c|c|}
\hline & Tzeltal word & -etik plural & -Vltik plural & $\begin{array}{l}\text { Distributive } \\
\text { plural -tikil } \\
\text { ("place of...") }\end{array}$ & $\begin{array}{l}\text { Reduplicated } \\
\text { plural } \\
\text { ("multiple...") }\end{array}$ \\
\hline trail, pathway & $b e$ & beetik & - & - & bebetik \\
\hline road & $\begin{array}{l}\text { belalkaro ['trail } \\
\text { for cars'], } \\
\text { karetera }(<\mathrm{Sp} .)\end{array}$ & $\begin{array}{l}\text { belalkaroetik, } \\
\text { kareteraetik }\end{array}$ & belalkaroiltik & - & - \\
\hline town & $\begin{array}{l}\text { lum [cognate } \\
\text { with 'earth'] }\end{array}$ & lumetik & - & - & lumlumtik \\
\hline $\begin{array}{l}\text { land with trees } \\
\text { on it }\end{array}$ & k'inal & k'inaletik & k'inaleltik & - & - \\
\hline $\begin{array}{l}\text { empty land, e.g. } \\
\text { pasture where } \\
\text { you tie up a } \\
\text { bull }\end{array}$ & $\begin{array}{l}\text { jochol k'inal } \\
\text { 'empty land' }\end{array}$ & jochol k'inaletik & jochol k'inaleltik & - & - \\
\hline $\begin{array}{l}\text { land resting, } \\
\text { fallow for 5-6 } \\
\text { years }\end{array}$ & $\begin{array}{l}\text { unin k'inal } \\
\text { 'young land' }\end{array}$ & unin k'inaletik & unin k'inaleltik & - & - \\
\hline $\begin{array}{l}\text { land with mature } \\
\text { trees }\end{array}$ & $\begin{array}{l}\text { yijil k'inal } \\
\text { 'mature land' }\end{array}$ & yijil k'inaletik & yijil k'inaleltik & - & - \\
\hline $\begin{array}{c}\text { land with coffee } \\
\text { trees planted }\end{array}$ & kajpejal & - & $\begin{array}{l}\text { kajpejaltik or } \\
\text { kajpejaleltik }\end{array}$ & - & - \\
\hline $\begin{array}{l}\text { area planted } \\
\text { with banana } \\
\text { trees }\end{array}$ & lo'bal & $\begin{array}{l}\text { lob aletik } \\
\text { (banana fruit, } \\
\text { not trees) }\end{array}$ & $\begin{array}{l}\text { lo'baleltik } \\
\text { (banana trees } \\
\text { area) - }\end{array}$ & - & \\
\hline $\begin{array}{l}\text { land with bulls } \\
\text { pastured on it }\end{array}$ & wakax & $\begin{array}{l}\text { wakaxetik } \\
\text { (multiple bulls) }\end{array}$ & wakaxeltik & - & - \\
\hline $\begin{array}{l}\text { land with horses } \\
\text { pastured }\end{array}$ & kawayu & $\begin{array}{l}\text { kawayuetik } \\
\text { (multiple } \\
\text { horses) }\end{array}$ & kawayuiltik & - & - \\
\hline cornfield & $k^{\prime}$ altik & k'altiketik & - & - & $\begin{array}{l}\text { k'alk'altik } \\
\text { (preempts -tikil) }\end{array}$ \\
\hline $\begin{array}{l}\text { former garden, } \\
\text { fallow for a } \\
\text { year or two }\end{array}$ & wank'altik & - & - & - & wank'alk'altik \\
\hline $\begin{array}{l}\text { smoke-place } \\
\text { (where } \\
\text { burning fields) }\end{array}$ & ch'ail 'smoke' & - & $\begin{array}{l}\text { ch'aileltik, } \\
\text { tojkaleltik (in } \\
\text { the air in } \\
\text { general) }\end{array}$ & - & - \\
\hline house & na & naetik & & & nanatik \\
\hline school & eskwela & eskwelaetik & eskwelailtik & - & - \\
\hline $\begin{array}{l}\text { land of PN (e.g. } \\
\text { land of the } \\
\text { pointy-assed } \\
\text { people) }\end{array}$ & $\begin{array}{l}(\text { slum) sk'inal } \\
P N,(\text { e.g. sk'inal } \\
\text { tz'ukitetik) }\end{array}$ & slum sk'inaletik & - & - & - \\
\hline
\end{tabular}

\subsection{Terms for parts and regions of landscape}

The landscape domain reflected in the terms in Table 2 relates to one other conceptual domain by virtue of entering into lexical relations with terms in the domain of body parts. 
Table 4

Terms for features and attributes of the soil and plant covering

\begin{tabular}{lllll}
\hline & Tzeltal word & -etik plural & -Vltik plural & $\begin{array}{l}\text { Distributive plural -tikil } \\
\text { ('place of...') }\end{array}$ \\
\hline weeds & wamal & wamaletik & wamaleltik & - \\
thorns & ch'ix & ch'ixetik & - & ch'ixtikil \\
grass & ak' & ak'etik & ak'ileltik & - \\
stone & ton & tonetik & - & tontikil \\
gravelly stones & xixinton & xixintonetik & xixtoniltik & xixintontikil \\
soft stone & kex & kexetik & - & kextikil \\
mud & ajch'al & - & ajch'aleltik & - \\
flower & nichim & nichimetik & nichimaltik & - \\
wood (stuff) & te' & te'etik 'trees' & te'ilaltik 'tree area' & te'tikil 'forest, wilderness' \\
pine tree, Pinus spp. & taj & tajetik & tajaleltik & - \\
kind of tree, Acacia spp. & xaxib & xaxibetik & xaxibaltik & - \\
Oak Quercus spp. & jijte' & jijte'etik & jijte'altik & - \\
\hline
\end{tabular}

They are a target of metaphor with body parts as the source domain. ${ }^{9}$ Whether this is metaphor or a looser form of analogy is a moot point: the body part system used with inanimate objects is based on geometry and shape. But with landforms the shapes are more amorphous and the analogy is perhaps looser.

For talking precisely about locations at particular parts or regions of the landform features designated by the landform terms, the body part/relational noun system described in Section 3.2 comes into play. Just as you can use body part terms as spatial relators to specify the location of an object in relation to some part of another physical object (e.g. jol na 'head house' [i.e. on top of the house], pat na 'back house' [at the back of the house], yelaw na 'its-face house' [at the door side, i.e. the face part of the house]), the same body part terms apply to landscape features: $y$-elaw witz' 'its-face mountain' [at the face (flat-side) of the mountain], jol witz 'head mountain' [on top of the mountain], pat witz 'back mountain' [at the back side or far side of the mountain] (see Fig. 8). Note that the word pat 'back' applied to houses can have any one of three meanings, referring to (1) the entire outside of the house, all four sides, (2) the side opposite to the front side where the door is, or (3) the back of the house calculated deictically from the perspective of a viewer at the front of the house (like English 'behind'). Applied to mountains, however, pat is restricted to deictic usage (3), with the 'back' calculated in relation to the location of speaker or other deictic origo. Other part terms also apply to mountains, for example $y$-ok witz 'its-base mountain' [where it rises out of the ground], by analogy to the base of a tree, which is also $y$-ok. These part terms refer both to places (e.g. There's a cow standing ta yok witz 'at the base of the mountain') and to types of landform (e.g. jol witzetik 'tops of mountains' tend to have trees on them).

\footnotetext{
${ }^{9}$ Landscape terms do not, however, seem to be themselves a source of metaphor - at least I have not found any cases of, for example, the metaphorical use of witz 'mountain/hill' for large things, or ch'en 'cliff/cave' for hard faces or recesses in things. Flora and fauna are, however, sometimes sources of metaphor (e.g. nichim 'flower' is used in traditional prayers to refer to saints). And natural forces - lightning, fire, for example - can be attributed to shamans as the expression of their magical power.
} 


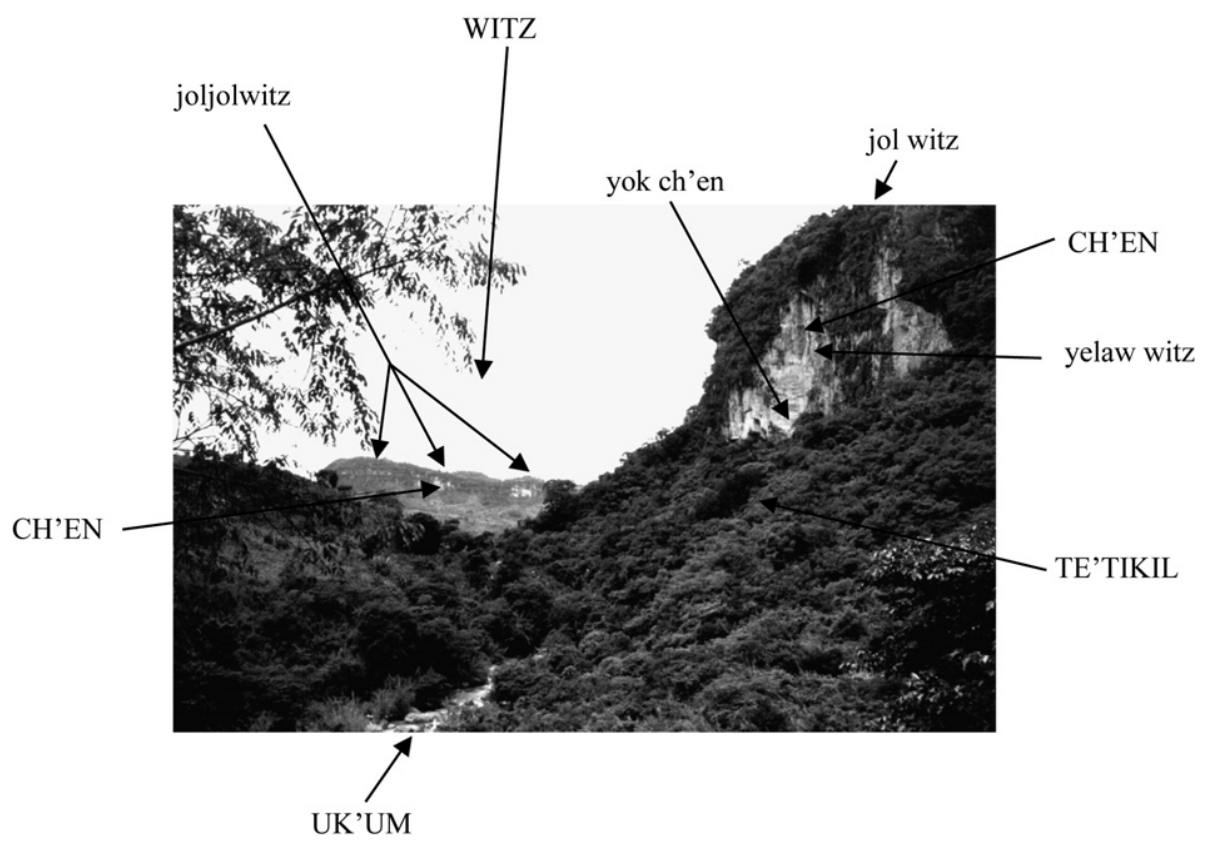

Fig. 8. Body parts of landscape features.

Two terms label regions of the landscape as a whole: the unpossessed bare nominals ajk'ol 'uphill' and alan 'downhill'. One talks routinely in terms of going to 'uphill' or 'downhill' in general (e.g. to some unspecified part of the region uphillwards), or in particular (e.g. in Majosik', people speak of going ta alan meaning specifically to their cornfields in hot country).

In addition, in some respects the landform terminology maps into the uphill/downhill system in the same way as inanimate objects can, with possessed relational nouns. For example, in a stack of tortillas, the topmost tortilla is said to be $t a s$-ba' at its top periphery', with the bottom-most tortilla being ta $y$-e'tal, 'at its bottom periphery'; here the terms make reference to the vertical axis. This same terminology applies to the landscape in the designations of parts/regions of rainbows (again, the vertical axis), but it also can make reference to the absolute (south/north) axis and apply to agricultural fields, with the top (uphillwards) edge of the field being $t a s$ - $b a$, the downhillwards edge being $t a y$-e'tal, as shown in Fig. 9.

But it is individual landform features, construed as objects with definable parts, to which these part- and region-terms apply. There is no sense that the landscape as a whole is construed in Tzeltal by analogy to a body, with the head being uphill for example and the feet downhill. ${ }^{10}$

\footnotetext{
${ }^{10}$ Although people do talk of the eastern direction - where the sun rises - as y-e'tal balamilal 'the bottom-edge of the world', this is not opposed to s-ba balamilal as the western direction; rather, $s$-ba balamilal refers to the earth's surface. Tenejapans do, however, say that you should not sleep with your head towards 'downhill' (i.e. south), nor can you be buried in that orientation.
} 


\section{cornfields}

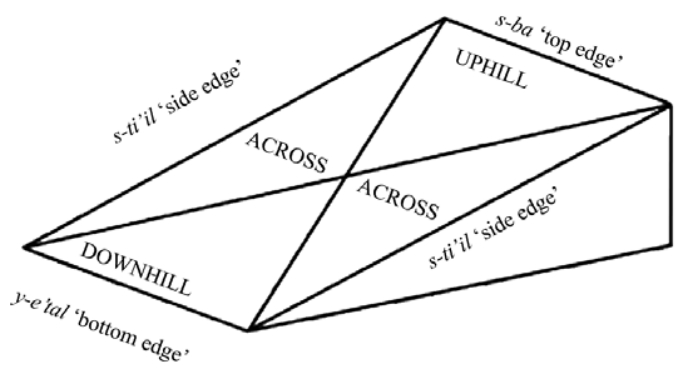

tortillas

$s-b a$ 'top (of pile)'

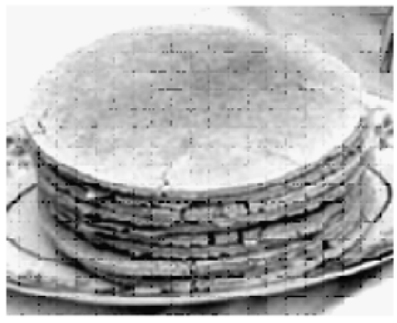

$y$-e'tal 'bottom (of pile)'

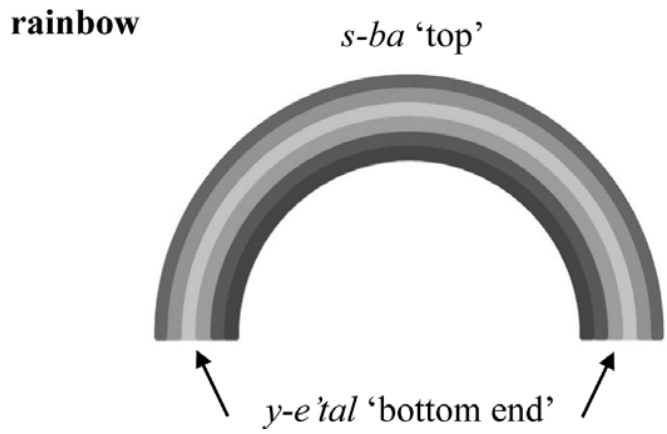

Fig. 9. Absolute edge terms for cornfields, pile of tortillas, rainbow.

\subsection{Integrity of the 'landscape domain' as a categorial system}

Is there an identifiable semantic domain of landscape in Tzeltal? Judging by the terms in Tables 2-4, I suggest that there is, but it is a category somewhat more general than the English term 'landscape' conveys. It is, rather, landscape construed as the physical environment - natural objects like mountains are not distinguished lexically from other, less permanent, physical features of the environment. For example, the special plurals apply not just to large-scale landscape features (witztikil 'mountain area') but to characteristics of the soil (xixintontikil 'small stones area') or plant cover (ch'ixtikil 'thorny area'), and even to features that are temporary due to land use (ch'aileltik 'smoky region') or weather conditions (ajch'aleltik 'muddy place').

Landform and manmade landscape terms appear to form a categorial system with semantic integrity: they refer to objects and regions characterized by particular object properties in the physical environment. But unlike terms in some other semantic domains - for example, life form terms, well documented for Tzeltal (Berlin et al., 1974, for plants, Hunn, 1977, for animals) - the names for landscape objects are not organised internally into relations of hierarchy through partonymy or taxonomy, or relations of opposition; these are labels for individual objects or areas identifiable in the landscape. As individual objects or areas they can be construed as having parts (e.g. edge, side, face), but these do 
not all fit into an overarching taxonomy. In this respect, they are similar to terms for celestial objects (e.g. $k$ 'aal 'sun', $u j$ 'moon', ek' 'star') and for atmospheric conditions (e.g. $i k$ ' 'wind', ja'al 'rain', bat' 'hail', tokal 'cloud', chawok 'lightening, thunder', sejk'ubit 'rainbow'). The word for 'world', balamilal, is in no way construed as a unique beginner, with mountains, rivers, etc. seen as parts of the world. ${ }^{11}$

As we have seen, partynomy comes in when referring to parts and regions of a given landscape object. The landscape domain is lexically and conceptually related to the semantic domain of body parts, and to the uphill/downhill frame of reference for spatial reckoning. But there is no relationship to less physical domains like kinship, except by association (clans are associated with particular parajes, for example). Similarly the relation to the spiritual world is one not of metaphor but of association. Caves, cliffs, and mountains are intimately associated with spiritual beings, and crosses are set up at particular caves, cliffs, waterholes, and paraje boundaries which receive regular ritual attention from a designated ritual specialist. The whole territory of Tenejapa is associated with the mythological culture-hero Kajkanantik, and specific places are associated with his travels throughout the land.

We now turn to consider the relationship between landscape terms, which label types of land form and environmental region, and place names, which label individual tokens of them. The categorization and labelling of landscape features, largely by means of common nouns, relates closely to place-naming, which in Tzeltal draws heavily on landscape features.

\section{Place names (PN) as a form class}

\section{1. 'Place'}

Is the primary denotation of place names a place, or an occupation site of a physical/ cultural entity? Places or regions are conceptually distinct from objects, with the latter having definite boundaries (Mark and Turk, 2003; citing Gibson, 1979). What notion of 'place' can one identify in Tzeltal?

The linguistic evidence in Tzeltal is equivocal. Of course you can readily ask 'where' things are (banti ay X? 'Where is X?'), and these 'things' can be either objects (e.g. 'Where is the machete?') or named places (e.g. 'Where is San Cristóbal?'). Indeed, the 'where' word banti enters into answers to where-questions to indicate emphasis on 'the place where', both for events, as in:

$\langle 7\rangle$ ja' te banti ochon ta eskwela

'It was there at where I entered the school'

and for places named with PNs:

$\langle 8\rangle$ ja' te banti Pokolum/Majosik'/Jobel

'It's at where Pokolum/Majosik'/Jobel (is)'

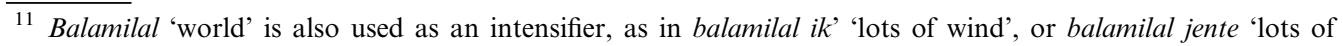
people'. 
This contrasts with answers to where-questions solely with preposition plus Placename (as in examples $\langle 14\rangle-\langle 15\rangle$ below).

Another perspective on Tzeltal conceptions of place comes from the word $y$-awil. This is a possessed nominal meaning 'its-place', but 'place' with rather a specialized meaning. Stationary things with a fixed location which could in principle be different (buildings, large furniture) have a $y$-awil, so one can say things like:

$\begin{array}{llllll}\langle 9\rangle \quad \text { ay-otik } & \text { ta } & \text { y-awil poko ch'ulna } & \text { namej. } \\ \text { EXIST-1plincl } & \text { PREP } & \text { 3E-place old church } & \text { long ago } \\ \text { 'We are at its-place (of the) } & \text { old church long ago.' }\end{array}$

meaning we are at the place where the old church used to be. Similarly:

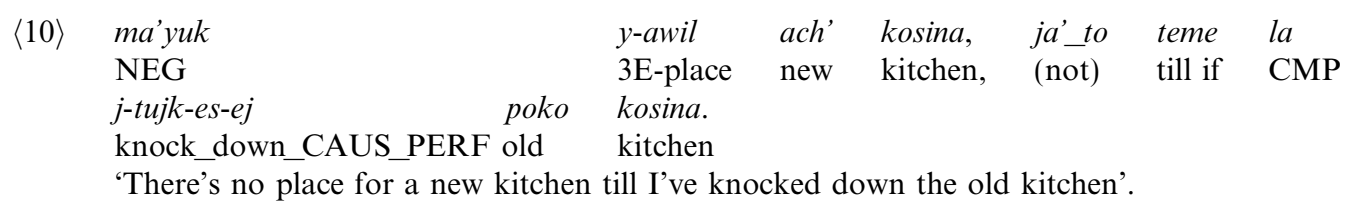

which will then go in its 'place', i.e. in the physical spot that it occupied. But things that move around - including humans, animals, cars - do not have a y-awil, or, if they do, it is the place where they belong (e.g. humans in their house, god in his heaven) or where they come from (e.g. woolen clothes from Chamula, water pots from Tenam). Trees, mountains, rivers do not have a $y$-awil, since individual ones could not be in a different place.

This suggests that entities labelled by place names, which do not have a $y$-awil, are not conceptualized as places (in the sense of $y$-awil) but rather as objects in the world.

\subsection{Formal properties of place names}

Some of the important place names in Tenejapa and its environs are given in Tables 57. These names can be monomorphemic and unanalyzable (e.g. Matzab, Jolom), but the majority are binomials and often semantically transparent (e.g. Kurus ch'en 'cross' + 'cave', Tzonte'witz 'tzonte' [a parasitic plant] + 'mountain'), labelling physical objects, landscape features, or (putative) historical events (e.g. the name Majosik' < 'hit-PERF sik' [a kind of swift]'), very few are trinomials (e.g. Jme'tik takin witz 'madam money mountain', the Tzeltal name for the municipio of Juaquitepec (about $30 \mathrm{~km}$ east of Tenejapa), referring to the story of the origin of this mountain from a money-excreting burro). A handful of PNs incorporate verbs: for example nitoj ijkatzil '(he) pulled load' names a place ta yajk'ol tal te yakan wakaxe 'above the Cow's Foot', on the trail to Lum; it is named for a mythological event (when the culture-hero Kajkanantik arrived there he stopped and tightened up the cords tying his load).

Names for socially constructed geographic entities - municipios, towns, parajes - have somewhat different properties from the PNs in Table 5. They are integrated into the wider Mexican context, and those for municipios and towns therefore have a Spanish name, to which a Tzeltal name in almost all cases corresponds (at least, within a radius of about $100 \mathrm{~km}$ ). With a few exceptions the Tzeltal name is preferentially used in this community for Tzeltal-speaking municipios, but for Tzotzil-speaking ones in many cases not the Tzeltal name but the municipio's saint's name is used (e.g. San Pero for San Pedro 
Table 5

Place names for landscape entities in and around Majosik'

\begin{tabular}{|c|c|c|c|}
\hline Name & gloss & Location, explanation for name & $\begin{array}{l}\text { Alternate } \\
\text { Spanish name? }\end{array}$ \\
\hline
\end{tabular}

\begin{tabular}{ll}
\hline $\begin{array}{l}\text { Mountains } \\
\text { Matzab }\end{array}$ & \\
Jojmut & \\
Kurusch'en & 'Grackle' (bird \\
Palech'en & 'cross cliffs' \\
Oxebwitz & 'priest cliffs' \\
K'ayobil & 'three mountain \\
& \\
Turuwit & \\
Majosik' & \\
Jolom & \\
Sakipat & \\
Mekantzuil & \\
Majomut & \\
Kelemton & 'white back' \\
Tzonte'witz & 'hit bird' \\
Yaxjemel & 'boy stone' \\
'treemoss \\
Tz'ik & mountain' \\
& 'green landslide' \\
& untranslatable
\end{tabular}

Rivers and streams
Tanate'
yuk'umal xpayil ja'
yuk'umal Trapicha
yuk'umal tzajal
ch'en
yuk'umal nuxib
kawayu
yuk'umal ch'en max
yuk'umal ch'i'bal
yuk'umal yalbante' -
sk'inal san pero
yuk'umal chikja'
yuk'umal Yochib

untranslatable 'boiling water river' 'sugarcane press river' 'red cliffs river'

'horse-washingplace river' 'monkey cave river' untranslatable 'waterfall river' 'burn-water river' '(water)-enteringplace river'

\section{Cliffs and caves}

Ti'ch'en

\section{Kurusch'en \\ Ch'en na jojmut}

Ch'en max

'lips/door cave'

'cave house of grackle bird' 'cave/cliff monkey' mountain the southernmost Tenejapan paraje is named for peak above Tenejapa Center

cliff face with cross the paraje is named for in Lum, associated with story of priest the three mountains the paraje is named for this and the next four mountains form the southern border of Majosik'

ala turul ala witz, "the mountain is pointytopped"

ya smajik sik' "they hit swifts"

in Chenalho' territory, visible from Majosik'

in Chenalho' territory, visible from Majosik'

in Cancuc territory, visible from Majosik'

in Chamula territory, named for tzonte' [tree moss] on its top

in Chenalho'; if there is a landslide just green gravel comes falling down

very high mountain visible from upper Majosik', $30 \mathrm{~km}$ away in the land of Mrs. Money

Mountain",

northern border of Tenejapa

a beja' in paraje Majosik'

big river at northern end of Tenejapa, associated with a place where sugar was made the river is below Red Cliffs, border of Chenalho' crossing place into Colonia, in Chenalho' territory

a beja' that runs into Nuxib Kawayu

a beja' that runs into Nuxib Kawayu

in Chenalho'

river below (north of) Yochib, at the border of Oxchuc

enters earth above (south of) Yochib, borders Oxchuc and Tenejapa

in paraje of Nabil; "when we come across the level land in front of it, our feet sound as if we were knocking on it's door."

caves the paraje Kurus Ch'en is named for in Lum; grackles sleep there
Tres Cerros 
Table 5 (continued)

\begin{tabular}{|c|c|c|c|}
\hline Name & gloss & Location, explanation for name & $\begin{array}{l}\text { Alternate } \\
\text { Spanish } \\
\text { name? }\end{array}$ \\
\hline Ch'en j'ijk'al & $\begin{array}{l}\text { 'cave/cliff } \\
\text { blackman' }\end{array}$ & $\begin{array}{l}\text { in Chorro, Chenalho'; associated with } \\
\text { the Blackman of folklore }\end{array}$ & \\
\hline Tzajal ch'en & 'red cliff' & $\begin{array}{l}\text { cliffs above Majosik', over the border in } \\
\text { Chenalho'; color is reddish }\end{array}$ & \\
\hline \multicolumn{4}{|l|}{ Water places } \\
\hline Banabil & & $\begin{array}{l}\text { in Chamula municipio; lake where jalame'tik of Banabil } \\
\text { puts her clothes }\end{array}$ & \\
\hline Yalbante' & & high waterfall visible from Majosik', but in Chenalho' & \\
\hline Yochib & $\begin{array}{l}\text { 'its entering } \\
\text { place' }\end{array}$ & $\begin{array}{l}\text { market/place where river enters ground on the Oxchuk/ } \\
\text { Tenejapa border }\end{array}$ & \\
\hline$X^{\prime}$ och ja' & 'water enters' & $\begin{array}{l}\text { place in Lum where water from several beja'etik enters } \\
\text { ground, to reemerge in Chenalho' }\end{array}$ & \\
\hline
\end{tabular}

Chenalho', Sam Mikel for San Mikel Mitontik; see Table 6). Municipios have distinct identities, associated not only with their own saint, but with distinctive dress and particular products.

Traditionally, settlements in Tenejapa have Tzeltal names (see Table 7). In a few cases they also have a Spanish name that is used (e.g. Tres Cerros alternates with Oxeb Witz in local usage). In the case of large parajes, names of smaller barrios within them are the locally used Tzeltal names rather than the name identifying the overarching legal entity. Areas that were formerly ranches owned by Spanish-speaking Mexicans are known as pinkas (from Sp. finca); one of these, just north of Majosik', was owned by a Ladino in living memory (when it was known as Pinka Cármen) but has now been sold to the local Tzeltal inhabitants and is known as Portiyo. Recently created parajes tend to have Spanish names (for example Santa Rosa, Libertad, Tres Pozo).

More ad hoc places may also get labelled with place names or standardized descriptors on the basis of things or events associated with them; these are more variable in their usage according to locality. They are often useful for route descriptions or localizing particular people or events (e.g. along the trail to Lum, Chonoj chilja' 'they sold corn beer', is a place named for the spot where men traditionally set up and sold corn beer).

Note that trails and rivers are treated differently than other landscape features receiving place names: their names are descriptive, including the designation belal PN 'trail PN' (e.g. belal K'ankujk, belal Pakte'ton) and yuk'umal PN 'its river PN', respectively, as if their identity as labelled in the place name is not sufficient to identify them as a trail or river. As one consultant said, 'Roads, trails, do not get names, they are named for where they are.' The same applies to crosses marking places of religious significance, which are named for their corresponding mountain (sakipat, jolom, turuwit, majosik', etc.) or water feature (e.g. ch'i'bal, xpayil ja').

Tzeltal place names do not seem to have anything in common with other proper nouns, displaying no sign of morphological relationship to personal names and clan names, for example. Nor do they have morphosyntactic features distinguishing them sharply from common nouns. The normal conditions for identifying proper names in English - absence of definite descriptions, inability to occur with indefinite determiners, quantifiers, plurals, 
Table 6

Names for large socio-political entities: municipios, towns

\begin{tabular}{|c|c|c|c|}
\hline Name & Gloss? & Reason for name & Spanish name \\
\hline \multicolumn{4}{|c|}{ Municipios (Tzeltal): } \\
\hline Yaxal lum & 'green land' & $\begin{array}{l}\text { named this because very beautiful } \\
\text { land }\end{array}$ & Yajalón \\
\hline Chi'lum & 'sweet land' & & Chilón \\
\hline Xijtalja' & '? + water' & & Sitalá \\
\hline Bajch'ajom & & & Bachajon \\
\hline $\begin{array}{l}\text { slumal Jme'tik } \\
\text { Tak'in Witz }\end{array}$ & $\begin{array}{l}\text { 'land of madam money } \\
\text { mountain' }\end{array}$ & $\begin{array}{l}\text { name is associated with tak'in } \\
\text { (money) that the mountain gave out }\end{array}$ & Juaquitepec \\
\hline Sibakja' & '? + water' & & Sivacá \\
\hline Okosinko & & & Ocosingo \\
\hline Tenam & & & Tenango \\
\hline K'ankujk & & & San Juan Cancuc \\
\hline Tenejapa & & & Tenejapa \\
\hline Oxchujk & & & Oxchuc \\
\hline Chanal & & & Chanal \\
\hline Tzontajal & $\begin{array}{l}\text { tzontajal means } \\
\text { something like } k^{\prime} i b \text { [pot]- } \\
\text { place }\end{array}$ & & Amatenango \\
\hline \multicolumn{4}{|c|}{ Municipios (Tzotzil): } \\
\hline $\begin{array}{l}\text { Chenalho', San } \\
\quad \text { Pero }\end{array}$ & & $\begin{array}{l}\text { water comes out of the cave in } \\
\text { Chenalho' center }\end{array}$ & San Pablo Chenalhó \\
\hline Sam Mikel & & & San Miguel Mitontic \\
\hline sk'inal Chamo & & & San Juan Chamula \\
\hline$K^{\prime}$ ina & & borders Tenejapa to the south & San Miguel Huistán \\
\hline Sotz'leb & 'land of bats' & & San Lorenzo Zinacantán \\
\hline San Andres & & & San Andres Larráinzar \\
\hline $\begin{array}{l}\text { Pantelho',Santa } \\
\text { Katarina }\end{array}$ & & & Santa Catarina Pantelhó \\
\hline Chachihuitan & & & San Pablo Chalchihuitán \\
\hline Tzimajobel & & & Simojovel \\
\hline Jimox Jol & '? + head' & & Teopisca \\
\hline Sam Bartol & & & $\begin{array}{l}\text { San Bartolome', also called } \\
\text { Venustiano Carranza }\end{array}$ \\
\hline \multicolumn{4}{|l|}{ Towns } \\
\hline Lum & & & Tenejapa \\
\hline Jobel & & & San Cristóbal \\
\hline Tuxta & & & Tuxtla Gutierrez \\
\hline Komitan & & & Comitan \\
\hline Mejiko & & & México \\
\hline
\end{tabular}

or numbers - do not apply in the Tzeltal case: you can, in the right context, say things like Jobel-etik, 'San Cristóbals', bayel Jobel-etik 'lots of San Cristóbals', or te Jobele, 'the San Cristóbal'. For example:

〈11〉 ma'yuk cheb lum Tenejapaetik, pero cheb Pakte'tonetik.

'There aren't two towns (called) Tenejapa, but there are two Pakte'tons.'

$\langle 12\rangle$ pero la stejk'anik PAN te Zinacantan.

'But the Zinacantán [a municipio] stood up PAN (a political party) (in the election).' 
Table 7

Names for sociopolitical entities in Tenejapa ${ }^{a}$

\begin{tabular}{|c|c|c|c|}
\hline Name & Gloss & Status, reason for name & $\begin{array}{l}\text { Spanish } \\
\text { name }\end{array}$ \\
\hline Amak'il & & unanalyzable & no \\
\hline Oxebwitz & 'three mountains' & there are three prominent mountains there & Tres Cerros \\
\hline Portiyo & & formerly pinka Portillo & Portillo \\
\hline Majosik' & & named for mountain, ya smajik sik' "they hit swifts" & no \\
\hline Pach' & & $\begin{array}{l}\text { former barrio of Majosik', now a paraje in its own } \\
\text { right }\end{array}$ & \\
\hline Kokiltik & & weekly market across the border in Mitontik & Chalam \\
\hline (Majben chauk) & & $\begin{array}{l}\text { formerly a paraje, now split into several but still use } \\
\text { this name for the larger area }\end{array}$ & no \\
\hline Pakte'ton & 'flattened stone' & $\begin{array}{l}\text { barrio in Majben Chauk; maybe because there are flat } \\
\text { stones there }\end{array}$ & no \\
\hline Joma nichim & 'pierced flower' & $\begin{array}{l}\text { barrio in Majben Chauk; associated with a flower } \\
\text { with a 'pierced' inside }\end{array}$ & no \\
\hline Ch'ixtontik & 'thorn'+ 'stone' & "place of thorns and stones" & no \\
\hline Ch'ixaltontik & 'thorn'+ 'stone' & "place of thorns and stones" & no \\
\hline Kurus pilal & 'cross pillar'? & $\begin{array}{l}\text { barrio in Majben Chauk, where a cave seems to have } \\
\text { pillars; maybe }\end{array}$ & no \\
\hline Jabenal & & barrio en Majben chauk & no \\
\hline Yetz'uk'um & 'river'? & & no \\
\hline Poko lum & 'old town' & $\begin{array}{l}\text { barrio in Sibanil ja'; site of old town (prior to current } \\
\text { Lum) is there }\end{array}$ & \\
\hline Juxalja' & $?+$ 'water' & & no \\
\hline Sibak' te'el & 'fireworks + stick' & they used to explode fireworks there & no \\
\hline Ch'ajkomaj & & unanalyzable & no \\
\hline P'olkem & & barrio in Ch'ajkomaj & no \\
\hline Ch'ul ja' & 'holy water' & barrio en Yax'anal; water exists there & no \\
\hline Kul ak'tik & 'place of kul'ak' vine' & & no \\
\hline Kotol te' & & 'standing_on_all_fours tree'? & no \\
\hline Yochib & 'entering place' & water enters ground there & plaza Yochib \\
\hline Pajal ton & 'equal stone' & lots of stones there & no \\
\hline Xojlej & "entering place" & a valley, 'entered' into the mountainside & Kanyada \\
\hline Nabil & 'lake' & used to be a lake there & no \\
\hline Xixintonil & 'small stones' & lots of xixinton there & no \\
\hline Tz'ajkbil jok' & & $t z^{\prime}$ ajkubil is the name of the piled up stones for a dam & no \\
\hline Lum & 'town' & Tenejapa Center & Tenejapa \\
\hline Ok'och & & unanalyzable & no \\
\hline Kurus ch'en & 'cross cliff' & there is a cross at the cliff & no \\
\hline Tzajal ch'en & 'red cliffs' & $\begin{array}{l}\text { there are 'red' cliffs there; cliffs in Chenalho' territory; } \\
\text { where the sun sets in Majosik' }\end{array}$ & no \\
\hline Yax anal & & & no \\
\hline Balun k'anal & 'blue/green' + ? & there's a little mountain, 9 levels, it steps up & no \\
\hline Banabil & 'top + lake' & top of the water on the lake that is there & no \\
\hline Chana' & & unanalyzable & no \\
\hline Matzab & & named after the mountain Matzab & no \\
\hline Winik ton & 'man + stone' & $\begin{array}{l}\text { barrio in Matzab; maybe a man tripped over a stone } \\
\text { there }\end{array}$ & no \\
\hline Ach'lum & 'new town' & a recent lum/paraje & no \\
\hline
\end{tabular}

a These are listed roughly from north to south. This is not an exhaustive list, and those in brackets are names of former parajes that appear on the maps in Figs. 2 and 10, but which have now been split up into several smaller parajes. A number of new parajes (elevated to this status because they have acquired a school and local government representatives) are not listed here. 
$\langle 13\rangle$ tup' ta k'aal te Nuxib Kawayu.

'The Nuxib Kawayu [a river crossing place] dried up from the sun.'

Non-usability with determiners is usually taken as one diagnostic of proper nouns, and in Tzeltal determiners are obligatory with common nouns in cases where the referent has been already mentioned, but not with proper nouns and place names. In Tzeltal locative expressions, like in English ones, you do not normally use a determiner with a place name:

$\langle 14\rangle$ I went to Jobel. (*the Jobel *this Jobel)

$\langle 15\rangle$ I went through (*the) Nuxib Wakax.

But in Tzeltal you must use the definite determiner te with all nouns, including personal names and PNs, if the noun is preposed (and hence in focus):

$\langle 16\rangle$ a. in te Xune 'as for Xun [girl's name], ...'

b. in te eskwelae 'as for the school, ...'

$\langle 17\rangle$ in te Jobele, muk'ul lum. in te Majosik', ja' muk'ul paraje, yan te Kulak'tik, ch'in stukel. 'As for the San Cristóbal, (it's a) big town. As for the Majosik', it's a big paraje, but the Kulak'tik in contrast is a small one.'

In locative expressions, place names occur as adjuncts of place after a preposition (baon ta Jobel 'I went to San Cristóbal') just as do other ground-denoting nominals, including landscape terms (baon ta yok witz 'I went to the foot of the mountain'). But unlike in Yukatek Maya (Bohnemeyer, 2001), PNs in Tzeltal are not the only nouns that head ground-denoting adjuncts without any spatial noun relators, just the preposition $t a$. So you can say ay ta $c N$ 'it is located at common-noun' or bajt ta $c N$ 'he went to common-noun', not only with just a few generic grounds: ta Lum 'to town', ta ch'ulchan 'to sky', but also with anything construable as a place (e.g. objects, regions):.

$\langle 18\rangle$ to physical object:

baon ta tza'niballeskwelalclinikalermitalch'iwich/poste

'I went to toilet/school/clinic/church/market/electricity post'

$\langle 19\rangle$ to geographical region:

baon ta pat k'inal, ta ajk'ol, ta alan

'I went to back-of-land [behind the mountain], to uphill, to downhill'

$\langle 20\rangle$ to place name:

baon ta Jobel, ta Tzakibiljok

'I went to San Cristóbal, to Tzakibiljok'

These observations lead me to conclude that place names are not a distinct form class of nouns in Tzeltal. In this they differ from personal first names, which receive a unique prefix (j-for male names, $x$-for female names), marking them off as a word class.

However, there is one possible criterion distinguishing PNs from common nouns as a class: the range of part terms which they can incorporate. In part-term-incorporating PNs the same system as for locatives is employed, but only a subset of the set of topological relation terms shown in Table 1 in fact is used, prominently including $t i$ ' 'lips, edge', $b a$ 
'top', but in one or two cases also $y$-akan 'its-foot', $y$-ok 'its base'. If this is a genuine semantic restriction (and not simply an accident of local topography), it might provide the basis for a criterion for a form class of PNs distinct from common nouns in Tzeltal.

\section{Place names, landscape terms, and spatial language}

\subsection{Spatial nouns collocating with landscape terms and place names}

A rather larger set of spatial relational nouns can take landform terms and PNs as arguments, either of a generic landscape term (like karetera 'road' - cf. ti' karetera 'edge of road') or of a PN '(like Ti'ch'en). Examples of these are given in Table 8.

Other spatial descriptors drawn from numeral classifiers and positional verbs also collocate with landform terms and PNs. Some of these indicate 3-D conceptualization of the categories via shape classifiers and descriptors:

$\langle 21\rangle$ s-p'ej-el

balamilal, ta s-pisil 3E-round.thing-ADJ world, PREP 3E-all 3E-be.round-NOM 'the whole world, in all of its roundness'
laj ta
ta toyiw s-p'ej-el
frost
3E-round.thing-ADJ
'The whole of Tenejapa died from frost.'
Tenejapa
Tenejapa

Some of these spatial descriptors reveal a conception of the world based on ancient Mayan cosmological beliefs, relatively fragmented nowadays:

$\langle 23\rangle$ ta olil ch'ulchan ya yok'esanik ok'es.

'In the middle [midst] of the sky they play pipes.'

〈24〉 ta ye'tal balamilal: te mach'a bwen yajwal te ch'ulchan, balamilal, mach'a la spas, ja' laj jtatik jwan lopez ta ye'tal balamilal. li' ay ta alan, melel xlochoj laj ta sk'ab te balamilal.

'at the bottom of the world [i.e. the part underneath the earth, vertically below it]: the one who is the true owner of the sky, the world, the one who made it, they say it's Mr. Juan Lopez at the bottom of the world. Here he is below, really he holds the world in his upturned hand.'

Fragments of these traditional beliefs are kept alive by religious rituals, and by stories of the travails of jalame'tik ('holy mother', the moon) and jch'ultatik ('holy father', the sun), as well as the tz'ukitetik ('pointy-assed people') said to live ta ye'tal balamilal 'under the earth', or ta kaniltik 'underneath us', where the sun goes after it sets. The sun passes so close to their heads they pack mud on their heads for protection. They have pointy butts, cannot sit down, and eat only smoke.

The constraints on what spatial nouns can collocate with PNs seem to derive from how the referents are physically construable in terms of shape (e.g. whether you can imagine that Tzajal Ch'en has a 'mouth/edge'). The restrictions on spatial relators' combinatorial abilities with PNs suggest that the places labelled with PNs are construed as 2D regions with centers (e.g. you can be ta yolil Lum 'at the middle of Tenejapa Center'), peripheries (e.g. you can be ta xujk ch'en 'at the cliff's side'), and boundaries (e.g. you can be ta yanil 
Table 8

Body part/relational nouns combined with landscape terms and place names (body part and relational noun terms are underlined)

\begin{tabular}{|c|c|}
\hline & Gloss, interpretation \\
\hline \multicolumn{2}{|l|}{ (s)-pat 'back' } \\
\hline pat witz ay, ta s-pat Turuwit. & $\begin{array}{l}\text { 'It [the paraje of Pakte'ton] is behind the mountain, at } \\
\text { Turuwit's back.' [from perspective of speaker in Majosik'] }\end{array}$ \\
\hline ta s-pat Tzajalch'en/Majosik' & $\begin{array}{l}\text { 'at the back of Tzajalch'en, Majosik'=beyond these mountains } \\
\text { (the far side) from where speaker is }\end{array}$ \\
\hline \multicolumn{2}{|l|}{ (s)-ba 'top' } \\
\hline $\begin{array}{l}\text { s- } \underline{\text { ba }} \text { Tzajalch'en } \\
\text { s- } \underline{\text { ba }} \text { Jobel (=ti' Jobel) }\end{array}$ & 'top of Tzajalch'en'=s-jol 'its-head' \\
\hline ta s-ba $* \operatorname{lum}$ & 'top of Jobel' not possible \\
\hline $\begin{array}{l}\text { ba ch'en, y-an ch'en, and place names Ba Ch'en, } \\
\text { Yan Ch'en }\end{array}$ & 'top of cliff, below cliff' \\
\hline (s)-jol 'head' & \\
\hline $\begin{array}{l}\text { ta s-jol Tzajalch'en/Matzab/Majosik' (usable in } \\
\text { relation to mountains, e.g. where the road } \\
\text { comes down into Majosik'). But not in }\end{array}$ & $\begin{array}{l}\text { 'at the head of Tzajalch'en/Matzab/Majosik'. But not } \\
\text { applicable to Jobel, as road doesn't come down into it from } \\
\text { head of mountain }\end{array}$ \\
\hline
\end{tabular}
relation to towns or parajes (*ta sjol Jobel)

(s)-ti' 'mouth, lips, edge'

ta s-ti' Jobel/Lum

but not ta s-tí $*$ Tzajalch'en

te Ti'ch'ene, lom toyol koel

(s)-chikin 'ear, corner'

ta X-chikin Matzab/Majosik' (or ta s-ti'il)

But not*Jobel

y-elaw 'face'

ta y-elaw Tzajalch'en/Lum/*Jobel

'at the lips/mouth/edge of Jobel' - this is where the town runs out, at its edge where the houses stop

But not in relation to mountains

'The Ti'ch'en [cliffs] are very high downwards'

[very high/tall]

'at the ear of Matzab/Majosik' (but not Jobel)'

\section{(s)-ch'ujt}

jipil ta ch'uit ch'en ay te kurus (at Kuruston)

tey ay pale a, nap'al ta s-ch'ujt (at Palech'en) ta X-ch'ujt Tzajalch'en/Majosik' (or ta y-elaw) but not *Jobel

\section{y-olil 'middle'}

ta y-olil Jobel/Lum

but not *Tzajalch'en

ta y-olil Nabil (if lake, but not if paraje)

\section{y-util 'inside'}

ayotik ta y-util jobel

ta y-util lum (or ta y-olil)

\section{y-ok 'base, lower limbs'}

ta y-ok/y-ok-inab Tzajalch'en/Matzab but not $*$ Jobel $/ *$ Lum (since they are flat)

'at the face of Tzajalch'en' (the cliff), but not Jobel

'hanging on the belly of the cliff/cave is the cross [at Kuruston]'

'there's a priest there, he's stuck to its (the cliff's) belly 'at the belly of Tzajalch'en/Majosik' - these mountains have bellies, the flat parts. But not for Jobel, no mountain called Jobel there.

'in the middle of San Cristobel/Tenejapa center', but not Tzajalch'en

'in the middle (underneath) the water of Nabil (lake)'

'we are inside San Cristóbal' i.e. in the middle of the town 'inside the earth'

only high things like a mountain or cave have yok, not flat towns. 
Table 8 (continued)

\begin{tabular}{|c|c|}
\hline & Gloss, interpretation \\
\hline \multicolumn{2}{|l|}{ xujk 'side' } \\
\hline ta xujk Tzajalch'en/Majosik'/Jobel & Both mountains and towns have $x u j k$ 'sides' \\
\hline ta $\underline{\text { xujk }}$ Jobel= $\underline{\text { ti' Jobel }}$ & $\begin{array}{l}\text { e.g. Jobel - bayel a lok'ix naetik ta xujkxujk Jobel 'lots of } \\
\text { houses sprang up at the sides of San Cristóbal' }\end{array}$ \\
\hline ta y-anil 'below, northwards of' & $\begin{array}{l}\text { applicable to any physical object, including mountains, rivers, } \\
\text { sinkholes, etc. }\end{array}$ \\
\hline \multicolumn{2}{|l|}{ ta y-ajk'ol 'above, southwards of' } \\
\hline $\begin{array}{l}\text { ay y-ajk'ol Jobel ay banti ya xyalik xulem } \\
\text { tak'in, y-anil bel Jobel ta banti ya xlok' bel } \\
\text { carretera Komitan }\end{array}$ & $\begin{array}{l}\text { 'The above-(side) of Jobel is where the airplanes land (i.e. at } \\
\text { the airport); the downhill side of Jobel is where the Komitan } \\
\text { road exits' }\end{array}$ \\
\hline $\begin{array}{l}\text { ta y-anil Lum, ta y-ajk'ol Lum [yanil Lum is the } \\
\text { alan side, even if higher. y-ajk'ol lum is the San } \\
\text { Cristóbal side, even if lower] }\end{array}$ & $\begin{array}{l}\text { 'The down-( side) of lum is the alan side, the above-side of lum } \\
\text { is the ajk'ol side' }\end{array}$ \\
\hline
\end{tabular}

ch'en 'below/north of the cliff'). You can also be 'near' PN (with the adjective nopol 'near').

\subsection{Place names and the absolute system of spatial reckoning}

How do Tzeltal speakers describe where named places are in relation to each other? Here the absolute system is called into play: the whole region construed as an inclined plane for these purposes. PNs with spatial relators utilizing the 'uphill/downhill/across' axes specify whether a place is 'above' [southwards], 'below' [northwards], 'side' [acrossways, i.e. in an east or west direction in relation to], 'corner' [diagonally placed in reference to], 'sunset' [westwards of] 'sunrise' [eastwards of] in relation to the ground place. Another spatial element is routinely introduced with adverbial directionals, indicating which direction ('awaywards', 'comingwards' [towards], or 'crossways') the referent lies in relation to the speech event. These are illustrated in the following examples (relational nouns are underlined; directionals are in roman); the spatial relationships described can be understood by reference to Fig. 10:

$\langle 25\rangle$ Jobel, ajk'ol ay yu'un Majosik'.

San Cristóbal is uphillwards of Majosik'.

〈26〉 Banabil, ma ba meru y-ajk'ol Lum, ta s-xujk nax ay jtebuk.

'Banabil is not truly uphill of Lum [Tenejapa Center], it's to its-side a bit.'

$\langle 27\rangle$ Oxeb Witz, meru lok'ib k'aal, jich ta s-tz'eel ini.

'Oxeb Witz is really at the sun's exit, like this to the side.' [gesturing eastwards, from Majosik']

〈28〉 Tzajal Chen, y-anil Lum, ta s-tz'eel ay yu'un Majosik'.

'Tzajal Chen is below town, to its-side in relation to Majosik'.

〈29〉 Kokiltik, malib k'aal ay yu'un Tenejapa.

'Kokiltik [a market in Mitontik] is to the setting sun in relation to Tenejapa'.

$\langle 30\rangle$ Chilom, ta meru alan, ta jelawel te lumal jme'tik Takin Witz.

'Chilom (is) to downhill, beyond ['crossways'] the land of Madam Money Mountain.' 


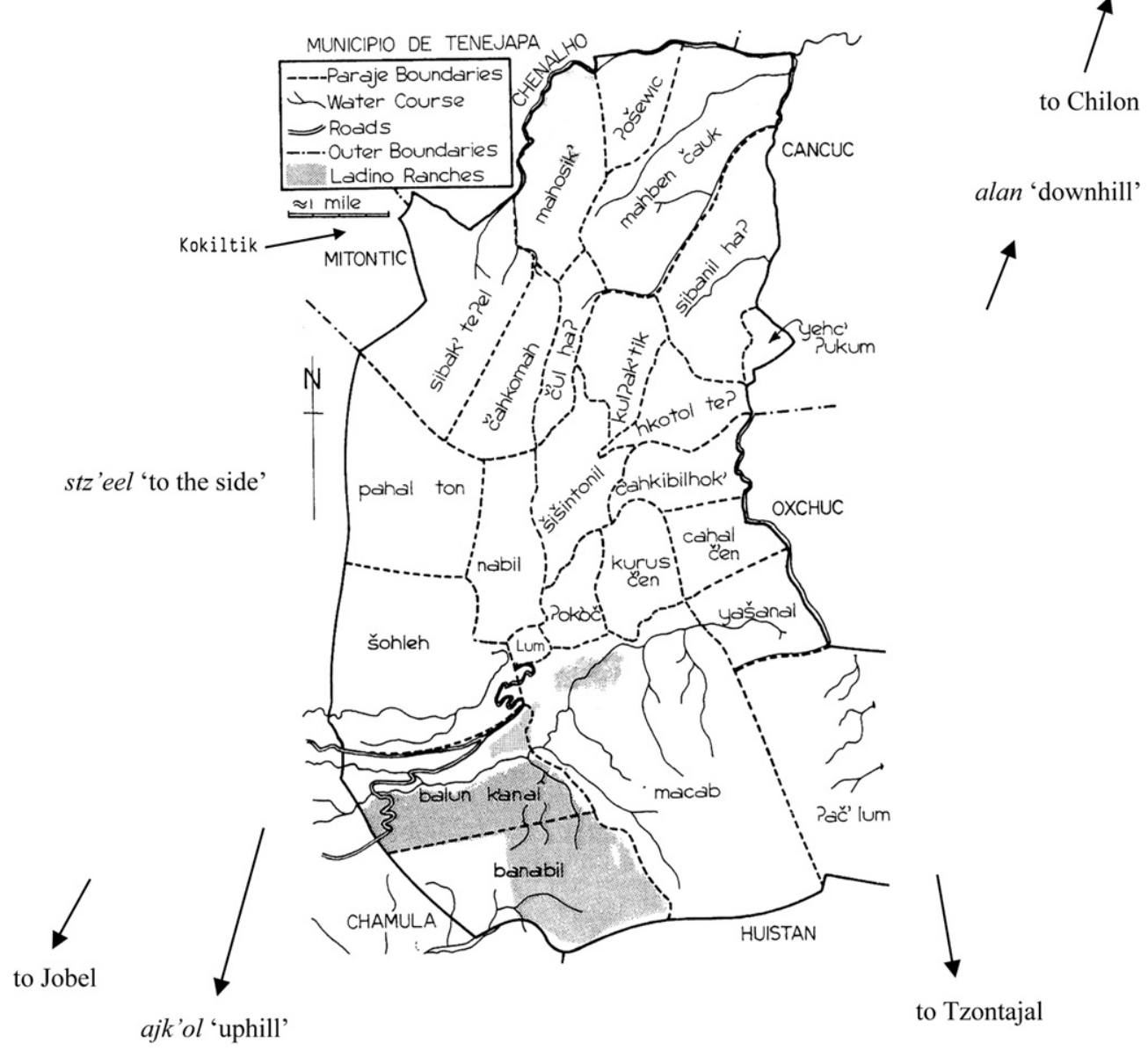

Fig. 10. Uphill/downhill/across places in relation to each other (map from Hunn, 1977, p. 8).

These absolute descriptions are equally applicable to mountains and other landscape features, e.g:

〈31〉 K'ayobil, ta s-xujk Turuwit, ta y-anil Turuwit.

'K'ayobil is to the side of Turuwit, below (north of) it.'

〈32〉 Jolom, y-ajk'ol s-na mamal j-antun tz'ujkin.

'Jolom is above [uphillwards/south of] old man Antun Tz'ujkin's house.'

Such spatial descriptions of landscape features in relation to each other, and to the movement of people and objects through them, are a pervasive aspect of everyday discourse in Tzeltal, essential for example to any narrative about a journey, or to any activity requiring moving objects around the land. (For a similar case in a radically different context, hunter-gatherers in Namibia, see Widlock, 2008). 


\subsection{Place names and their denotations}

What kinds of things receive place names? Some are Spanish-culture influenced, names for settlements, markets, parajes, municipios required by government. Others are wholly indigenous, grounded in cultural beliefs and practices - e.g. regions (alan/ajk'ol, k'ixin/ sikil k'inal), sacred places (springs, mountain and paraje crosses). Others are ad hoc - landmarks useful for route descriptions or specifying meeting points (e.g. Pakal Na 'mud-brick house', where there used to be a mud-brick house at a crucial trail intersection, or Yakan Wakax 'foot of cow', a saliently footshape-dented stone on the trail to Lum) or named because they are particularly salient (a large waterfall visible from far away, Yalbanja', but not all waterfalls). Things that are not generally named include agricultural fields, hunting areas, woods, topographic areas (e.g. marsh, plains), institutions like churches, schools (these are named in the Spanish system but Tenejapans do not use the names except in bureaucratic interchanges with Mexican authorities).

Are there identifiable boundaries to the places that are named? There clearly are for settlements (a house is either in or out of a given paraje, not half-in), but not for mountains, rivers, lakes, caves, the names for which can identify a region around the physical landmark that is the focus of the name. There is not always the same denotation for a place name and its landform name; for example, Oxebwitz 'Three mountains' is the name of a paraje prominently characterized by three mountain peaks, but the paraje is much larger than the area covered by the mountains. Similarly, Yochib names the specific place where a river enters the ground in a cave, but the place name extends to a whole region where the borders of three municipios (Tenejapa, K'ankujk, Oxchuk) meet and where traditionally a market was held; here a large settlement called Yochib has sprung up. And Tanate' now names the area across the northern boundary river where some Tenejapan families in search of cheap land have settled in Chenalho' territory. Tanate' was the name of the prior ranch of quite different extent (named after the river of that name), again distinct from Colonia (the colonia Puebla, in Spanish) which is now the corresponding political entity. Place names can thus be polysemous, referring to entities with different boundaries at different levels of scale.

\section{Conclusions}

The previous discussion makes it clear that there are at least three kinds of determinants of landscape terminology in Tzeltal, as in other languages (Bohnemeyer et al., 2004): (i) perceptual salience, (ii) interactional affordances, and (iii) cultural importance. These are of course intertwined, and all three are discernable in the Tenejapan case.

Perceptual salience is relevant in Tzeltal landscape terminology at least in picking out which kinds of landscape features get labelled, large, visually prominent ones like mountain peaks being good candidates. It is also relevant in determining the boundaries of some categories; caves and lakes, for example, are more clearly bounded by discontinuities in physical features than are mountains or rivers. Where boundaries are not provided by landscape features but are important - especially boundaries of cornfields and family land plots - they are artificially installed, tim or ujkum tok'oy trees and stones being the traditional boundary markers, now sometimes replaced by fences of wood or wire.

Interactional affordances (cf. Gibson, 1979) are clearly relevant in the Tenejapan context especially for water sources: in this permeable limestone landscape water is a precious 
resource and rivers, rivulets, marshland, and springs welling up from the ground are all important for cultural exploitation. Similarly, elawal 'place with a vista' areas are highly prized as sites for houses. And the words for areas of manmade cultivation and for features of the terrain (different kinds of rockiness, for example) are finely distinguished on the basis of how these areas are exploited and what constraints they place on their human users.

These interactional affordances are not really distinct from the cultural framing and exploitation of them. Cultural determinants perhaps also motivate the inclusion of manmade features like cultivated areas in the same class of terms as those labelling features of the natural environment. And cultural determinants are surely the most important influence on place names in Tenejapa, where for example bumps in the long ridges get honored with a PN depending on cultural construals of their importance. There are many cultural narratives about events (ritual journeys, mythical events) associated with particular kinds of places (especially mountains, caves, sinkholes). As in many traditional societies, the landscape is richly imbued with religious and mythological associations. Myths are associated with particular local places and storytellers expounding the myth can point with consistent accuracy to the places where parts of the story occurred; these may well supply the corresponding place names.

Of all the cultural ideas, beliefs and practices associated with the landscape in Tenejapa, the most wide-reaching is the uphill/downhill system of spatial reckoning. The cognitive template of 'uphill/downhill/across' is a cultural construct, deriving from the Tzeltal language and how people routinely use it to refer to spatial relations. While it does not provide a metaphor for the lexical domain of landscape terms and place names in general, it permeates speech about these places. You cannot talk in Tzeltal about where things are or where they are moving through the landscape without reference to this template.

\section{Acknowledgements}

This paper is based largely on fieldwork in Tenejapa conducted jointly with Stephen C. Levinson, and many of the insights into landscape and the uphill/downhill system are due to collaboration with him. I am also grateful to Tilman Harpe for help with formatting the figures.

\section{References}

Basso, K.H., 1984. Western Apache place-name hierarchies. In: Tooker, E. (Ed.), Naming Systems. American Ethnological Society, Washington, DC, pp. 78-94.

Berlin, B., Breedlove, D.E., Raven, P.H., 1974. Principles of Tzeltal Plant Classification. Academic Press, New York.

Bohnemeyer, J., 2001. Toponym Questionnaire. In: Levinson, S.C., Enfield, N.J. (Eds.), 'Manual' for the Field Season 2001. Max Planck Institute of Psycholinguistics, Nijmegen, pp. 55-61.

Bohnemeyer, J., Burenhult, N., Enfield, N.J., Levinson, S.C., 2004. Landscape terms and place names elicitation guide. In: Majid, A. (Ed.), Field Manual: Volume 9. Max Planck Institute for Psycholinguistics, Nijmegen, pp. 75-79.

Breton, A., 1979. Les Tzeltal de Bachajón. Laboratoire d'Ethnologie et de Sociologie Comparative, Nanterre.

Brown, P., 2006. A sketch of the grammar of space in Tzeltal. In: Levinson, S.C., Wilkins, D. (Eds.), Grammars of Space. Cambridge University Press, Cambridge, pp. 230-272.

Brown, P., Levinson, S.C., 1993. 'Uphill' and 'Downhill' in Tzeltal. Journal of Linguistic Anthropology 3 (1), 4674. 
Brown, P., Levinson, S.C., 2000. Frames of spatial reference and their acquisition in Tenejapan Tzeltal. In: Nucci, L., Saxe, G., Turiel, E. (Eds.), Culture, Thought, and Development. Erlbaum, Mahwah, NJ, pp. $167-197$.

Gibson, J.J., 1979. The Ecological Approach to Visual Perception. Houghton-Mifflin, Boston.

Hercus, L., Hodges, F., Simpson, J. (Eds.), 2002. The Land Is a Map: Placenames of Indigenous Origin in Australia. Pandanus Books, Canberra.

Hirsch, E., O’Hanlon, M. (Eds.), 1995. The Anthropology of Landscape: Perspectives on Place and Space. Clarendon Press, Oxford.

Hunn, E., 1977. Tzeltal Folk Zoology: The Classification of Discontinuity in Nature. Academic Press, New York.

Hunn, E., 1996. Columbia Plateau Indian place names: what can they teach us? Journal of Linguistic Anthropology 6 (1), 3-26.

Levinson, S.C., 1994. Vision, shape, and linguistic description: Tzeltal body-part terminology and object description. In: Haviland, J., Levinson, S.C. (Eds.), Spatial Conceptualization in Mayan Languages [special issue]. Linguistics 32 (4/5), 791-855.

Levinson, S.C., 2003. Space in Language and Cognition: Explorations in Cognitive Diversity. Cambridge University Press, Cambridge.

Levinson, S.C., Brown, P., 1994. Immanuel Kant among the Tenejapans: Anthropology as Empirical Philosophy. Ethos 22 (1), 3-41.

Mark, D.M., Turk, A.G., 2003. Ethnophysiography. Paper presented at: Workshop on Spatial and Geographic Ontologies, September 23, 2003.

Monad Becquelin, A., 1997. Parlons Tzeltal: Une Langue Maya du Mexicque. L’Harmattan, Paris.

Smith, B., Mark, D.M., 1999. Ontology with human subjects testing: an empirical investigation of geographic categories. American Journal of Economics and Sociology 58 (2), 245-272.

Smith, B., Mark, D.M., 2003. Do mountains exist? Towards an ontology of landforms. Environment \& Planning B: Planning \& Design 30 (3), 411-427.

Widlock, T., 2008. Landscape unbounded: space, place, and orientation in $\neq$ Akhoe Hai//om and beyond. Language Sciences 30, 362-380. 